


\section{Scenariostudie zeebaars}

Wouter Jan Strietman ${ }^{1}$, Erik Buisman ${ }^{1}$, J os Op de Weegh ${ }^{1}$, Jan Jaap Poos ${ }^{2}$

1 Wageningen Economic Research

2 Wageningen Marine Research

Dit onderzoek is uitgevoerd door Wageningen Economic Research in opdracht van en gefinancierd door het ministerie van Economische Zaken, in het kader van het Beleidsondersteunend onderzoek (projectnummer BO-20-010-140/KB-2016-010)

Wageningen Economic Research

Wageningen, maart 2017

RAPPORT

2017-008

ISBN 978-94-6343-150-7 
Strietman, W.J., Buisman, F.C., Op de Weegh, J., Poos, J.J., 2017. Scenariostudie zeebaars. Wageningen, Wageningen Economic Research, Rapport 2017-008. 36 blz.; 18 fig.; 5 tab.; 6 ref.

In dit rapport staan de resultaten van een analyse naar de potentiële impact van zeven mogelijke scenario's op de aanlandingen en economische opbrengsten van de Nederlandse schepen die commercieel op zeebaars vissen, uitgesplitst naar het type visserij. Deze analyse is uitgevoerd naar aanleiding van een vraag van het ministerie van Economische Zaken en op basis van de bij Wageningen Economic Research en Wageningen Marine Research aanwezige gegevens en modellen. Uit de analyse blijkt dat in de Nederlandse situatie, de handlijnvissers economisch gezien relatief het meest afhankelijk zijn van de zeebaars. De andere tuigcategorieën zijn op enkele staandwantschepen na (economisch gezien relatief veel) minder afhankelijk van zeebaars maar landen samen in absolute zin een vergelijkbare hoeveelheid zeebaars aan als de handlijnvisserij.

Trefwoorden: zeebaars, visserij, visserijbeleid, maatregelen, staandwant, flyshoot, lijnenvisserij.

This report contains the results of an analysis of the potential impact of seven possible scenarios on the landing and financial proceeds of Dutch ships commercially fishing seabass for each particular type of fishing. This analysis was conducted following a request from the Ministry of Economic Affairs and based on data and models of Wageningen Economic Research and Wageningen Marine Research. The analysis has shown that in the Netherlands, handline fisheries are economically most dependant on seabass. The other gear categories, with the exception of set net vessels, are economically less dependent on seabass, yet collectively land a similar amount of seabass as handline fisheries.

Key words: seabass, bass, measures, fisheries, handline fisheries, set gillnet fisheries, flyshoot fisheries

Dit rapport is gratis te downloaden op http://dx.doi.org/10.18174/410734 of op www. wur. nl/economic-research (onder Wageningen Economic Research publicaties).

(C) 2017 Wageningen Economic Research

Postbus 29703, 2502 LS Den Haag, T 07033583 30, E communications.ssg@wur.nl, www. wur. nl/economic-research. Wageningen Economic Research is onderdeel van Wageningen University \& Research.

\section{(cc) BY-NC}

Wageningen Economic Research hanteert voor haar rapporten een Creative Commons Naamsvermelding 3.0 Nederland licentie.

(C) Wageningen Economic Research, onderdeel van Stichting Wageningen Research, 2017 De gebruiker mag het werk kopiëren, verspreiden en doorgeven en afgeleide werken maken. Materiaal van derden waarvan in het werk gebruik is gemaakt en waarop intellectuele eigendomsrechten berusten, mogen niet zonder voorafgaande toestemming van derden gebruikt worden. De gebruiker dient bij het werk de door de maker of de licentiegever aangegeven naam te vermelden, maar niet zodanig dat de indruk gewekt wordt dat zij daarmee instemmen met het werk van de gebruiker of het gebruik van het werk. De gebruiker mag het werk niet voor commerciële doeleinden gebruiken.

Wageningen Economic Research aanvaardt geen aansprakelijkheid voor eventuele schade voortvloeiend uit het gebruik van de resultaten van dit onderzoek of de toepassing van de adviezen.

Wageningen Economic Research is ISO 9001:2008 gecertificeerd.

Wageningen Economic Research Rapport 2017-008 | Projectcode 2282200224

Foto omslag: Shutterstock 


\section{Inhoud}

Samenvatting $\quad 5$

S.1 Belangrijkste uitkomsten $\quad 5$

$\begin{array}{lll}\text { S.2 Overige uitkomsten } & 6\end{array}$

$\begin{array}{lll}\text { S.3 Methode } & 7\end{array}$

$\begin{array}{ll}\text { Summary } & 8\end{array}$

S.1 Key findings $\quad 8$

S.2 Complementary findings $\quad 9$

$\begin{array}{ll}\text { S.3 Method } & 10\end{array}$

1

Inleiding

11

1.1 Aanleiding $\quad 11$

$\begin{array}{lll}1.2 & \text { Doelstelling } & 11\end{array}$

$\begin{array}{lll}1.3 \text { Methode } & 11\end{array}$

$\begin{array}{lll}2.1 & \text { Economische resultaten en aanlandingen } & 14\end{array}$

$\begin{array}{lll}2.2 & \text { Historische ontwikkeling aanlandingen } & 15\end{array}$

2.3 Maandelijkse aanlandingen zeebaarsvisserij $\quad 16$

$\begin{array}{lll}2.4 & \text { Vangstgebieden aangelande zeebaars } & 17\end{array}$

$\begin{array}{lll}2.5 & \text { Aanlandingen vanuit de recreatieve visserij } & 17\end{array}$

$\begin{array}{lr}\text { Resultaten per scenario } & 18\end{array}$

$\begin{array}{lll}3.1 & \text { Inleiding } & 18\end{array}$

3.2 Scenario 1A: Volledig visverbod met alle tuigen die zeebaars vangen in alle kwadranten van waar nu zeebaars wordt aangeland ('zero catch') 18

3.2.1 Uitgangspunten en aannames 18

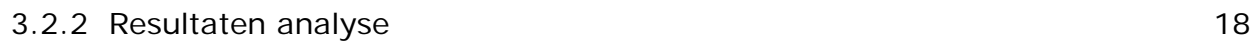

3.3 Scenario 1B: Aanlandverbod voor zeebaars uit kwadranten van waaruit nu zeebaars wordt gevist en aangeland $\quad 19$

3.3.1 Uitgangspunten en aannames 19

3.3.2 Resultaten analyse $\quad 19$

3.4 Scenario 2: Aanlandverbod voor het hele jaar voor zeebaars voor alle tuigen behalve lijnen en staandwant $\quad 20$

3.4.1 Uitgangspunten en aannames $\quad 20$

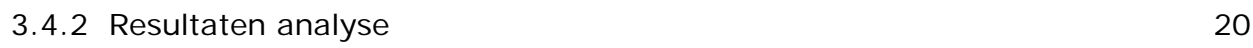

3.5 Scenario 3: Aanlandverbod voor het hele jaar voor zeebaars voor alle tuigen behalve flyshoot en gesleepte tuigen (demersaal) $\quad 21$

3.5.1 Uitgangspunten en aannames $\quad 21$

3.5.2 Resultaten analyse $\quad 21$

3.6 Scenario 4: Aanlandverbod voor het hele jaar voor zeebaars voor alle tuigen. Voor lijnen en staand want is het alleen in februari en maart verboden om zeebaars aan te landen en geldt voor de rest van het jaar een maximum van $1.000 \mathrm{~kg}$ per schip $\begin{array}{ll}\text { per maand } & 22\end{array}$

3.6.1 Uitgangspunten en aannames $\quad 22$

$\begin{array}{ll}3.6 .2 \text { Resultaten analyse } & 22\end{array}$ 
3.7 Scenario 5a: Visverbod voor het hele jaar voor alle tuigen die zeebaars vangen (flyshoot, lijnen, staandwant, demersaal en overig) in die kwadranten van waaruit nu het meeste zeebaars wordt aangeland (tot circa $75 \%$ van de huidige aanlandingen)

3.7.1 Uitgangspunten en aannames 23

3.7.2 Resultaten analyse $\quad 23$

3.8 Scenario 5b: Aanlandverbod voor zeebaars gedurende het hele jaar in die kwadranten van waaruit nu het meeste zeebaars aangeland wordt 24

3.8.1 Uitgangspunten en aannames $\quad 24$

$\begin{array}{ll}3.8 .2 \text { Resultaten analyse } & 24\end{array}$

$\begin{array}{lll}4.1 & \text { Inleiding } & 25\end{array}$

4.2 Aanlandingen zeebaars per scenario $\quad 25$

$\begin{array}{lll}5.1 & \text { Inleiding } & 27\end{array}$

5.2 Schepen verantwoordelijk voor $80 \%$ van de aanlandingen 27

$\begin{array}{lll}5.3 & \text { Aanlandingen staandwantvisserij } & 28\end{array}$

$\begin{array}{ll}5.4 & \text { Aanlandingen lijnenvisserij } \\ 5.5 & 29\end{array}$

$\begin{array}{lll}5.5 & \text { Aanlandingen in de flyshootvisserij } & 30\end{array}$

$\begin{array}{lll}6.1 & \text { Conclusies } & 32\end{array}$

6.2 Discussie 33

6.2.1 Discussie naar aanleiding van de zeven scenario's 33

6.2.2 Discussie naar aanleiding van de voor 2017 vastgestelde maatregelen $\quad 34$

Databronnen, literatuur en websites $\quad 35$ 


\section{Samenvatting}

\section{S.1 Belangrijkste uitkomsten}

In dit rapport geven we in 7 scenario's de resultaten weer van de potentiële impact van verschillende mogelijke beschermingsmaatregelen voor zeebaars op de aanlandingen en economische opbrengsten van de Nederlandse schepen die commercieel op zeebaars vissen, uitgesplitst naar het type visserij. Bij doorrekening van de scenario's is verondersteld dat alle visserijactiviteiten gelijk blijven ten opzichte van die in het basisjaar (2014) en dat daar waar visserijactiviteiten verboden worden geen alternatieve activiteiten worden ondernomen. De belangrijkste uitkomsten zijn als volgt:

- In 2014 werd circa 236 ton zeebaars aangeland door de Nederlandse beroepsvisserij. Hiervan werd door de flyshootvisserij het grootste deel aangeland (39\%), gevolgd door de lijnenvisserij (35\%), demersale visserij (19\%) en staandwantvisserij (7\%).

- Voor de lijnenvisserij en staandwantvisserij vormt zeebaars het grootste aandeel in de opbrengsten ( $84 \%$ en $11 \%$ respectievelijk); voor de flyshoot en overige demersale visserij is dit aandeel substantieel lager ( $6 \%$ en minder dan $1 \%)$.

Voor wat betreft de effecten per scenario zijn de resultaten als volgt (zie ook tabel S1):

- De aanlandingen van zeebaars dalen het meest in scenario's 1A en 1B (vrijwel volledig vis- of aanlandverbod voor zeebaars) en het minst in scenario 3 (aanlandverbod voor de flyshoot- en demersale visserij). (zie tabel $\mathrm{S} 1$ ):

- De winst en besomming van de flyshoot- en demersale visserij dalen het minst in scenario 3; De besomming daalt het meest in scenario $1 \mathrm{~A}$ en de winst in scenario $5 \mathrm{~A}$;

- In scenario's 1A en 5A, waar in beide gevallen een visverbod geldt, betekent een reductie van de toegestane aanlandingen waarschijnlijk in dezelfde mate ook een reductie in de vangst van zeebaars omdat hier een visverbod geldt voor de kwadranten van waaruit (veel) zeebaars wordt aangeland.

- In de overige scenario's wordt de reductie van aanlandingen niet bereikt door een visverbod maar een aanlandverbod. Naleving hiervan kan betekenen dat er nog wel gevist kan worden maar dat zeebaars wordt vermeden of overboord wordt gezet. Dit betekent dat de mate van overleving van belang is voor effectiviteit van de maatregel. Dit geldt met name voor scenario 1B, dat op papier het meest interessante scenario lijkt vanwege de sterke reductie van aanlandingen en de relatief geringe vermindering van de winst.

- Tegenover de grotere zekerheid die scenario's 1A en 5A bieden ten aanzien van de reductie van de vangsten staat wel een veel grotere daling van inkomsten voor de vloot dan in de overige scenario's. Scenario's 1A en 5A zullen bij gelijkblijvende kosten veel meer impact hebben op de winst dan de andere scenario's omdat er in bepaalde gebieden in zijn geheel niet meer gevist zal kunnen worden. Zo wordt er in scenario $1 \mathrm{~A}$ voor elke $\mathrm{kg}$ reductie in de aanlanding van zeebaars 623 euro aan besomming ingeleverd en 122 euro aan winst. In scenario 5A is deze reductie respectievelijk 334 en 172 euro per kilo. In de overige scenario's liggen de daling van besomming en winst per kg reductie in de aanlanding van zeebaars in de orde van de aanlandprijs van zeebaars (11-13 €/ kg) voor vissers. De verdelingseffecten over de verschillende vistuigcategorieën verschillen natuurlijk wel sterk voor de verschillende scenario's. 
Tabel S1 Effecten van maatregelen op aanlandingen en besommingen zeebaars in $2014(\mathrm{mln}$. $€$ )

\begin{tabular}{|c|c|c|c|c|}
\hline Scenario (mogelifke maatregelen) & $\begin{array}{l}\text { Aanlandingen } \\
\text { zeebaars (kg) }\end{array}$ & $\begin{array}{r}\text { Aanlandingen } \\
\text { als \% van } \\
2014\end{array}$ & $\begin{array}{l}\text { Verandering } \\
\text { totale besomming } \\
\text { a) }(\mathrm{m} / \mathrm{n}, €)\end{array}$ & $\begin{array}{r}\text { Verandering } \\
\text { winst a) } \\
(\mathrm{m} / \mathrm{n} . €)\end{array}$ \\
\hline $\begin{array}{l}\text { Scenario 1A - Volledig visverbod met alle tuigen } \\
\text { die zeebaars vangen in alle kwadranten van waar } \\
\text { nu zeebaars wordt aangeland ('zero catch') }\end{array}$ & 408 & 0,2 & $-146,72$ & $-28,82$ \\
\hline $\begin{array}{l}\text { Scenario 1B - Aanlandverbod voor zeebaars uit } \\
\text { kwadranten van waaruit nu zeebaars wordt gevist } \\
\text { en aangeland }\end{array}$ & 408 & 0,2 & $-2,81$ & $-2,81$ \\
\hline $\begin{array}{l}\text { Scenario } \mathbf{2} \text { - Aanlandverbod voor het hele jaar } \\
\text { voor zeebaars voor alle tuigen behalve lijnen en } \\
\text { staand want. }\end{array}$ & 97.439 & 41,3 & $-1,48$ & -1.48 \\
\hline $\begin{array}{l}\text { Scenario } 3 \text { - Aanlandverbod voor het hele jaar } \\
\text { voor zeebaars voor alle tuigen behalve flyshoot en } \\
\text { gesleepte tuigen (demersaal). }\end{array}$ & 135.520 & 57,4 & $-1,34$ & $-1,34$ \\
\hline $\begin{array}{l}\text { Scenario } 4 \text { - Aanlandverbod voor het hele jaar } \\
\text { voor zeebaars voor alle tuigen. Voor lijnen en } \\
\text { staand want is het alleen in februari en maart } \\
\text { verboden om zeebaars aan te landen en geldt } \\
\text { voor de rest van het jaar een maximum van } \\
1.000 \mathrm{~kg} \text { per schip per maand. }\end{array}$ & 95.701 & 40,5 & $-1,48$ & $-1,48$ \\
\hline $\begin{array}{l}\text { Scenario 5A - Visverbod voor het hele jaar voor } \\
\text { alle tuigen die zeebaars vangen (flyshoot, lijnen, } \\
\text { staandwant, demersaal en overig) in die } \\
\text { kwadranten van waaruit nu het meeste zeebaars } \\
\text { wordt aangeland (tot circa } 75 \% \text { van de huidige } \\
\text { aanlandingen). }\end{array}$ & 60.151 & 25,5 & $-58,75$ & $-30,33$ \\
\hline $\begin{array}{l}\text { Scenario 5B - Aanlandverbod voor zeebaars } \\
\text { gedurende het hele jaar in die kwadranten van } \\
\text { waaruit nu het meeste zeebaars aangeland wordt. }\end{array}$ & 60.151 & 25,5 & $-2,11$ & $-2,11$ \\
\hline
\end{tabular}

\section{S.2 Overige uitkomsten}

- Tijdens het afronden van dit rapport zijn de definitieve zeebaars beschermende maatregelen voor 2017 bekendgemaakt. ${ }^{1}$ Deze maatregelen wijken enigszins af van de in deze analyse doorberekende scenario's:

- Voor beroepsvissers met gesleept vistuig (onder andere flyshoot) geldt een bijvangstpercentage van $3 \%$ per reis/op het moment van controle met een maximale aanvoer van $400 \mathrm{~kg}$ per maand;

- Voor staandwantvissers geldt een maximale aanvoer van $250 \mathrm{~kg}$ per maand;

- Voor de handlijnvissers geldt dat er in de maanden januari en april tot en met december in totaal 10 ton zeebaars aangevoerd worden.

- Indien de maatregelen voor 2017 zouden worden toegepast op de aanlandingen in 2015 (het laatste jaar waarover in zijn totaal aanlandingsgegevens bekend zijn), dan zou dat de volgende effecten hebben gehad:

- In 2015 waren er 13 schepen in de flyshootvisserij die zeebaars hebben aangeland. Van deze 13 schepen waren er 11 die in één of meerdere maanden meer dan $400 \mathrm{~kg}$ hebben aangeland. Een eventuele aanlandbeperking van $400 \mathrm{~kg}$ zou in 2015 tot een reductie van $52.450 \mathrm{~kg}$ hebben geleid. Dit betreft ongeveer $62 \%$ van de aanlandingen van zeebaars door de flyshootvisserij. Een aanvullende beperking in toegestane aanlandingen van maximum $3 \%$ van het totale gewicht in zeebaars zou in 2015 geen aanvullend effect hebben gehad op de $400 \mathrm{~kg}$-maatregel; in alle gevallen zou de $400 \mathrm{~kg}$-regel beperkender zijn.

1 http://www. visned.nl/nl/nieuws/item/id/31263/visserij raad-geeft-goed-perspectief-voor-2017 
- In 2015 waren er 60 staandwantschepen die zeebaars hebben aangeland. Hiervan waren er 11 schepen die in één of meer maanden meer dan $250 \mathrm{~kg}$ aangeland. Aanlandingen boven $250 \mathrm{~kg}$ kwamen alleen voor in de maanden mei en juli-oktober. Een eventuele aanlandbeperking van $250 \mathrm{~kg}$ per maand zou in 2015 een reductie van $6.004 \mathrm{~kg}$ hebben betekend, dat is ongeveer $35 \%$ van de totale aanlandingen.

- In 2015 waren er 76 schepen in de lijnenvisserij die zeebaars hebben aangeland. Hiervan hebben er geen van allen meer dan $10.000 \mathrm{~kg}$ aangeland; alle schepen zaten daar (ruim) onder.

\section{S.3 Methode}

Het ministerie van Economische Zaken heeft aan Wageningen Economic Research en Wageningen Marine Research gevraagd een scenarioanalyse uit te voeren met betrekking tot mogelijke beschermingsmaatregelen voor zeebaars en de economische gevolgen daarvan voor de visserijsector. Deze analyse is uitgevoerd op basis van de bij Wageningen Economic Research en Wageningen Marine Research aanwezige gegevens en modellen.

In overleg met EZ zijn zeven mogelijke maatregelen (scenario's) geformuleerd die de commerciële visserij op zeebaars op verschillende manieren beperken. Deze zijn gebruikt als basis voor de doorberekening van de effecten op aanlandingen en opbrengsten op de belangrijkste tuigcategorieën waarmee zeebaars wordt gevangen en aangeland: flyshoot, staandwant, lijnenvisserij en overige demersale visserij (voor meer informatie over de methode, zie paragraaf 1.3). De uitkomsten van de scenario's kunnen beschouwd worden als indicatie van de impact van de onderliggende maatregelen.

Nadat eind 2016 de definitieve beschermende maatregelen voor 2017 bekend zijn geworden, is globaal in kaart gebracht wat dit zou kunnen betekenen voor de zeebaarsaanlandingen (zie hoofdstuk 6.2). Hiervoor is dus geen uitgebreide economische impact analyse uitgevoerd zoals voor de zeven scenario's. 


\section{Summary}

\section{S.1 Key findings}

This report presents the results of seven different scenarios about the potential impact of different protective measures for seabass on the landings and financial proceeds of Dutch ships that commercially fish seabass, for each particular type of fishing. The projection of these scenarios assumes that all fishing activities will remain level with those of the 2014 base year and that where fishing activities are banned, no alternative activities will be conducted. The key findings are as follows:

- In 2014, approximately 236 tonnes of seabass were landed by the Dutch fishing industry. Flyshoot fishing recorded the largest percentage of the total landings (39\%) followed by line fishing (35\%), demersal fishing (19\%) and set net fishing (7\%).

- Seabass makes up the largest percentage of proceeds for line fishing (84\%) and set net fishing $(11 \%)$, while this percentage is significantly lower for flyshoot $(6 \%)$ and other demersal fishing (less than $1 \%)$.

The effects per scenario have shown the following results (see table S1):

- The landing of seabass is reduced most significantly in scenarios 1A and 1B (a near-total landing ban on seabass) and the least in scenario 3 (landing ban for flyshoot and demersal fishing). (See table S1):

- The profit and proceeds of the landings for flyshoot and demersal fishing drop the least in scenario 3. The proceeds of the landings decrease most significantly in scenario $1 \mathrm{~A}$ and profits in scenario 5A.

- In scenarios 1A and 5A where a fishing ban applies, a reduction in permitted landings is likely to result in a reduction in the catch of seabass, as in these scenarios a fishing ban applies to the quadrants responsible for a high landing of seabass.

- In the other scenarios a reduction of landings is not achieved by a fishing ban, but rather through a landing ban. Adherence to this means that fishing activities can still take place, but that sea bass is avoided or thrown overboard. This means that the survival rate is important for the effectiveness of such a measure. This is especially applicable to scenario 1B which, on paper, appears to be the most effective scenario as a result of the marked reduction of landings and the relatively limited reduction of profit.

- However, the higher certainty with respect to the reduction of catch of scenarios $1 \mathrm{~A}$ and 5A comes with a significant reduction of income for the fleet which, in contrast, is markedly less in the other scenarios. Scenarios $1 \mathrm{~A}$ and $5 \mathrm{~A}$ will have a stronger effect on profit in the case of unchanged costs than the other scenarios, as fishing will no longer be possible in certain areas. In scenario 1A, 623 euros in proceeds of the landings and 122 euros of profit is lost for every kilogram reduction in the landing of seabass. In scenarios 5A, these losses are 334 euros and 172 euros respectively per kilogram. In the other scenarios, the decrease in proceeds of the landings and reduction in profit per kilogram for the landing of seabass are related to the landing price of seabass (11-13 €/ kg) for fishers. The distributional effects across the different fishing categories vary greatly for the different scenarios. 
Table S1 Effects of measures on landing and proceeds of the catch of seabass in 2014 (in millions of $€$ )

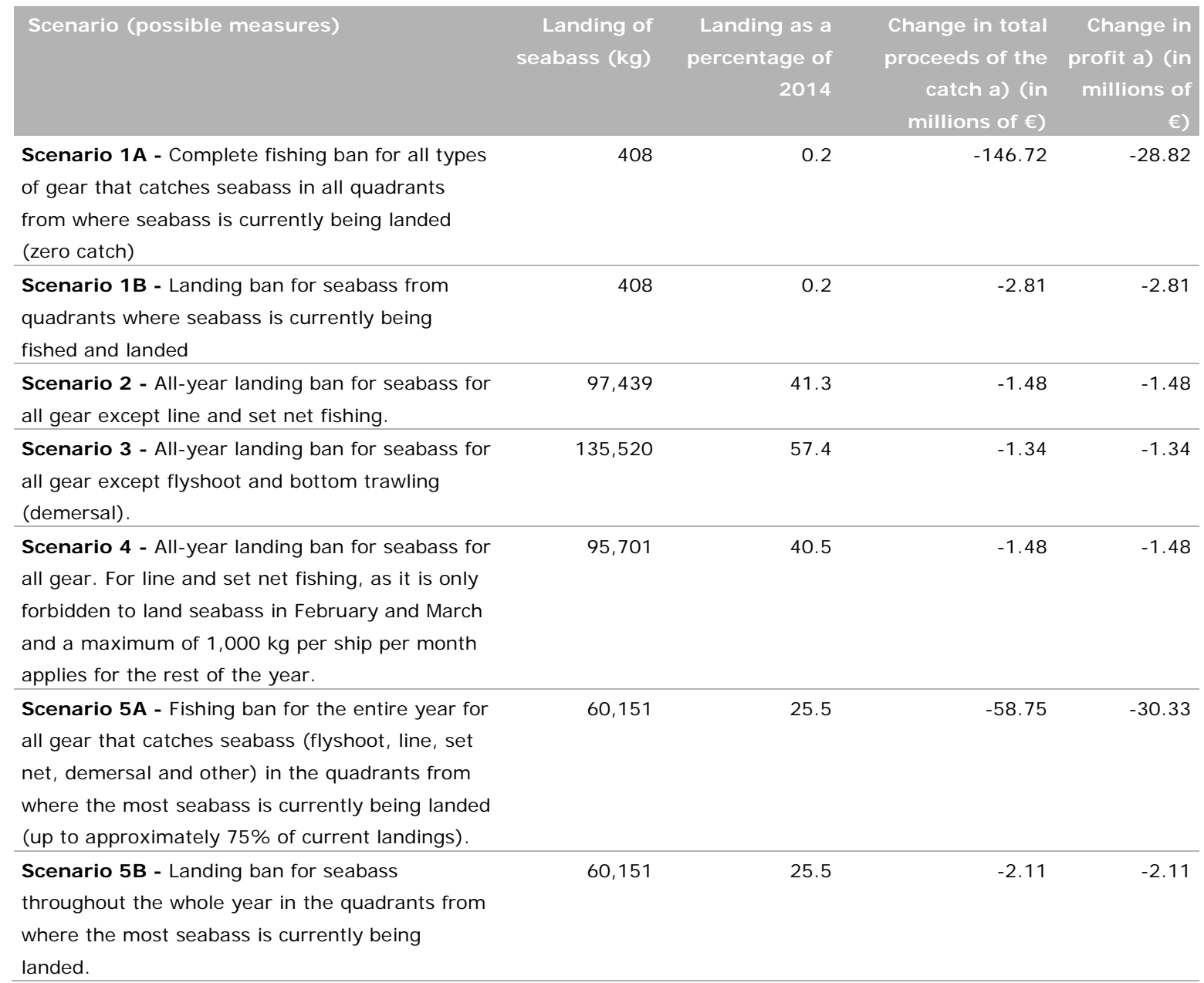

a) This concerns changes to the proceeds of the catch and profit of all ships that use line, set net, flyshoot and demersal fishing gear.

Source: VIRIS and the Farm Accountancy Data Network (Bedrijveninformatienet) of Wageningen Economic Research.

\section{S.2 Complementary findings}

- During the finalisation of this report the definitive protective measures for seabass for 2017 were announced. ${ }^{2}$ These measures differ from those projected in the scenarios of this analysis:

- For the bottom trawling fishing industry (including flyshoot), an incidental catch percentage of $3 \%$ per trip at the moment of monitoring applies with a maximum landing of $400 \mathrm{~kg}$ per month.

- For set net fishing, a maximum landing of $250 \mathrm{~kg}$ per month applies.

- For handline fishing, a closure of two months in February and March and a maximum catch limit of 10 tonnes per year will apply..

- If the 2017 measures had been be applied to landings in 2015 (the last year for which all landing data is available) this would have resulted in the following effects:

- In 2015, there were thirteen ships in the flyshoot fishing industry that landed seabass. Of these thirteen ships, eleven landed more than $400 \mathrm{~kg}$ in one or more months. A landing restriction of $400 \mathrm{~kg}$ in 2015 would have resulted in a reduction of $52,450 \mathrm{~kg}$. This amounts to approximately $62 \%$ of seabass landings by the flyshoot fishing industry. Any additional restrictions on the permitted landing of no more than $3 \%$ of the total weight in seabass would have had a supplementary effect on the $400 \mathrm{~kg}$ measure in 2015. In all cases, the $400 \mathrm{~kg}$ measure would have been more restrictive.

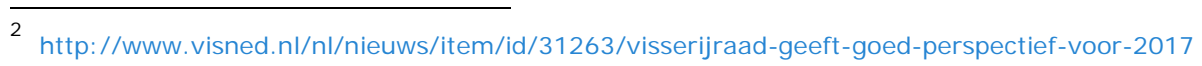


- In 2015, there were sixty set net fishing vessels that landed seabass. Eleven of these ships landed more than $250 \mathrm{~kg}$ in one or more months. Landings exceeding $250 \mathrm{~kg}$ only occurred in May and between J uly and October. A restriction of $250 \mathrm{~kg}$ per month would have resulted in a reduction of $6,004 \mathrm{~kg}$ in 2015 , amounting to $35 \%$ of total landings.

- In 2015 there were 76 ships in the line fishing industry that landed seabass. None of these landed more than $10,000 \mathrm{~kg}$. In fact, all vessels landed significantly less than this.

\section{S.3 Method}

The Ministry of Economic Affairs asked Wageningen Economic Research and Wageningen Marine Research to conduct a scenario analysis for the possible protective measures for seabass and the economic and financial consequences of such measures for the fishing sector. This analysis was based on data and models from Wageningen Economic Research and Wageningen Marine Research.

Together with the Ministry of Economic Affair, seven possible measures (scenarios) were formulated that restrict commercial seabass fishing in several different ways. These were used as a basis for a projection of the effects on landings and proceeds of the largest gear categories for seabass fishing and landing: flyshoot, set net, line fishing and other demersal fishing methods (for more information about this method see paragraph 1.3). The results of the scenarios can be considered as an indication of the impact of these measures.

When the definite measures for 2017 were announced at the end of 2016, a general observation was made of their potential impact on seabass landings (see Chapter 6.2) Thus, no extensive economic and financial impact analysis was conducted for this as it has been for each of the seven scenarios. 


\section{$1 \quad$ Inleiding}

\section{$1.1 \quad$ Aanleiding}

Het zeebaarsbestand staat er slecht voor. Het paaibestand neemt de laatste jaren sterk in omvang af en de visserijsterfte neemt toe. Daarmee nadert het bestand de 'gevarenzone' voor wat betreft duurzame visvangst. Voor de periode 2015-2016 heeft de Europese Commissie daarom strenge maatregelen ingevoerd om de zeebaars beter te beschermen en heeft in oktober 2016 een voorstel gedaan voor nog strengere maatregelen voor 2017. Dat voorstel is mede geformuleerd naar aanleiding van het 'zero catch' advies van ICES voor $2017 .^{3}$

Bij het proces om tot het nieuwe voorstel te komen om op Europees niveau zeebaars beter te beschermen is het ministerie van Economische Zaken (EZ) betrokken. In dit kader heeft EZ aan het Wageningen Economic Research (voorheen: LEI) en Wageningen Marine Research (voorheen:

IMARES) gevraagd om een scenariostudie uit te voeren naar de potentiële impact van zeven scenario's op aanlandreductie van zeebaars en op de economische opbrengsten van de Nederlandse schepen die commercieel op zeebaars vissen, uitgesplitst naar het type visserij.

\subsection{Doelstelling}

Het doel van dit onderzoek is om op basis van zeven scenario's inzicht te geven in de mogelijk effecten op aanlandingen en opbrengsten voor de belangrijkste vistuigcategorieën waarmee zeebaars wordt gevangen en aangeland. De uitkomsten van de scenario's kunnen beschouwd worden als indicatie van de impact van de onderliggende maatregelen.

\section{$1.3 \quad$ Methode}

Methodiek en uitgangspunten

In overleg met EZ zijn zeven mogelijke maatregelen (scenario's) geformuleerd die de commerciële visserij op zeebaars op verschillende manieren beperken. Deze zijn gebruikt als basis voor de doorberekening van de effecten op aanlandingen en opbrengsten voor de belangrijkste vistuigcategorieën waarmee zeebaars wordt gevangen en aangeland.

\section{Doorgerekende scenario's}

\section{- Scenario 1A}

Volledig visverbod met alle tuigen die zeebaars vangen in alle kwadranten van waar nu zeebaars wordt aangeland ('zero catch').

\section{- Scenario 1B}

Aanlandverbod voor zeebaars uit kwadranten van waaruit nu zeebaars wordt gevist en aangeland.

\section{- Scenario 2}

Aanlandverbod voor het hele jaar voor zeebaars voor alle tuigen behalve lijnen en staand want.

\section{- Scenario 3}

Aanlandverbod voor het hele jaar voor zeebaars voor alle tuigen behalve flyshoot en gesleepte tuigen (demersaal).

\section{- Scenario 4}

Aanlandverbod voor het hele jaar voor zeebaars voor alle tuigen. Voor lijnen en staand want is het

\footnotetext{
3 http://www.ices.dk/sites/pub/Publication\%20Reports/Advice/2015/2015/Bss-47.pdf
} 
alleen in februari en maart verboden om zeebaars aan te landen en geldt voor de rest van het jaar een maximum van $1.000 \mathrm{~kg}$ per schip per maand.

\section{- Scenario 5a}

Visverbod voor het hele jaar voor alle tuigen die zeebaars vangen (flyshoot, lijnen, staandwant, demersaal en overig) in die kwadranten van waaruit nu het meeste zeebaars wordt aangeland (tot circa $75 \%$ van de huidige aanlandingen).

\section{- Scenario 5b}

Aanlandverbod voor zeebaars gedurende het hele jaar in die kwadranten van waaruit nu het meeste zeebaars aangeland wordt.

\section{Vistuigcategorieën}

1. Demersale visserij

TBB (Boomkor), TB (Bodemtrawl), TBS (Garnalenkor), SUM (SumWing), QUA (Quadrig), PUK (Pulskor), PUL (PulsWing), OTT (Twinrig), OTB (bodem ottertrawl), PTB (Spanrieten bodem), SPR (Gepaarde Zegen), SV (Boot Zegens), SB (Landzegens) en SX (Zegens).

2. Flyshootvisserij (in feite is flyshootvisserij ook demersale visserij maar voor deze analyse apart genomen) SSC (Schotse Zegen) en SDN (Deense Zegen/Snurrevaad)

3. Lijnenvisserij LH (handlijnen en hengels), LHM (handlijnen en hengels mechanisch), LHP (handlijnen/ hengels handmatig), LLS (beuglijnen vast) en LNP (kruisnetten draagbaar).

4. Staand want GN (kieuwnet), GNS (kieuwnet staand net), GND (kieuwnet drijfnet), GTN (gecombineerde kieuwnet) en GTR (laddernet).

$\rightarrow$ NB: Een klein deel van de zeebaars wordt gevangen en aangeland door 'overige tuigen' (1,3\%). Dit is een zeer diverse groep tuigen. Omdat de opbrengst van zeebaars van deze tuigen zeer laag is en dit geen gerichte visserij betreft, wordt deze categorie in de analyse van de economische effecten buiten beschouwing gelaten.

I mpact van scenario's op aanlandingen, besomming en winst van de verschillende tuigcategorieën

- De economische impact wordt bepaald op basis van de effecten op besomming en winst. Besomming is de term die gebruikt wordt voor de opbrengst van vis bij verkoop aan wal.

- De uitkomsten van de scenario's kunnen beschouwd worden als indicatie van de impact van de onderliggende maatregelen.

- Voor de analyse van de economische effecten is 2014 als basisjaar gebruikt omdat dit het laatste jaar is waarvoor economische gegevens beschikbaar waren. Omdat 2014 geen representatief jaar is voor wat betreft de aanlandingen en populatie omdat deze beiden sindsdien significant lager zijn (zie ook figuur 2), zijn in grafieken en figuren waar het uitsluitend gaat om de aanlandingen de meest recente gegevens gebruikt (2015). Waar het gaat om de aanlandingen enerzijds en opbrengst, besomming of waarde anderzijds, is 2014 als uitgangspunt gebruikt. Omdat de aanlandingen in 2015 en 2016 verder zijn gedaald kunnen de hier berekende economische effecten beschouwd worden als indicatie van de mogelijke effecten van verdere beperkende maatregelen.

- Verondersteld is dat de visserijactiviteiten niet wijzigen ten opzichte van 2014. Dit betekent dat:

- ervan uit wordt gegaan dat door ieder schip precies evenveel trips naar dezelfde gebieden en met hetzelfde brandstofverbruik en kosten als in het basisjaar 2014 worden gemaakt.

- er ook van uit wordt gegaan dat in de scenario's waarin een visverbod is ingesteld voor bepaalde tuigen of bepaalde gebieden de verboden visserijactiviteit wordt gestopt zonder dat vervangende activiteiten worden ontplooid.

- In de praktijk, zullen vissers namelijk hun gedrag en activiteiten naar alle waarschijnlijkheid aanpassen aan de veranderde omstandigheden. In welke mate deze aanpassingen invloed hebben op de winst valt buiten de scope van dit onderzoek. ledere aanname over vervangende activiteiten met bijbehorende kosten en opbrengsten zou wat dat betreft speculatief zijn.

- Er is verondersteld dat de visserijactiviteiten niet wijzigen ten opzichte van 2014. Dit betekent dat ervan uit wordt gegaan dat door ieder schip precies evenveel trips

- In de scenario's waar een visverbod geldt is er verondersteld dat de variabele kosten van schepen proportioneel zijn met de gemaakte zeedagen. Bij een visverbod voor een gebied of seizoen dalen 
de variabele kosten dus met het percentage van de zeedagen dat de schepen in dit gebied of seizoen visten.

- In de scenario's met een aanlandverbod, worden uiteraard alleen de schepen beïnvloed die zeebaars aanlanden. Daarom worden hiervoor de effecten op de groep 'zeebaarsschepen' (schepen die tussen 2010 en 2016 zeebaars hebben aangeland) gepresenteerd.

- In de scenario's 1A en 5A waar een visverbod geldt voor schepen die met staand want, flyshoot, lijnen of demersale tuigen vissen, kunnen ook schepen worden getroffen die met deze tuigen vissen maar in het verleden geen zeebaars hebben aangeland. Daarom worden voor deze scenario's de effecten voor alle schepen die met deze tuigen vissen gepresenteerd.

- De economische impact is berekend door voor elk scenario te bepalen:

- welke economische waarde de zeebaars vertegenwoordigt, en welke waarde men potentieel misloopt bij de verschillende scenario's

- welke invloed dat heeft op de (totale) opbrengsten.

- De waarde is hierbij bepaald door gebruik te maken van de gemiddelde verkoopprijzen van zeebaars voor vissers uit 2014.

- De hiermee berekende economische impact is een indicatie van de werkelijke impact omdat er in deze analyse van uitgegaan wordt dat er geen alternatieven voorhanden zijn. In de praktijk zullen vissers hun gedrag en activiteiten naar alle waarschijnlijkheid echter aanpassen aan de veranderde omstandigheden (invoering van nieuwe maatregelen). In welke mate deze aanpassingen invloed hebben op de winst vergt een extra onderzoeksinzet die buiten de scope van BO-onderzoek valt.

- In de analyse berekenen we de effecten van maatregelen op de commerciële visserij. Omdat er geen (up-to-date) gegevens beschikbaar zijn van de aanlandingen en economische opbrengst van de recreatieve visserij valt deze categorie buiten de scope van BO-onderzoek. Analyse van de effecten op de recreatieve visserij zou nadere dataverzameling vereisen. In paragraaf 2.4 geven we wel een inschatting van de aanlandingen van de recreatieve visserij ten opzichte van de commerciële visserij.

- Tijdens het afronden van dit rapport zijn de definitieve zeebaars beschermende maatregelen voor 2017 bekendgemaakt; ${ }^{4}$ deze maatregelen wijken enigszins af van de in deze analyse doorberekende scenario's. Ondanks de verschillen geeft deze analyse echter wel inzicht in het economisch belang van zeebaars voor de verschillende groepen commerciële vissers (gegroepeerd naar tuigcategorieën) en in welke mate deze economische belangen beïnvloed kunnen worden door verschillende typen maatregelen.

4 http://www.visned.nl/nl/nieuws/item/id/31263/visserijraad-geeft-goed-perspectief-voor-2017 


\section{Economische resultaten en aanlandingen}

\subsection{Economische resultaten en aanlandingen}

Tabel 1 geeft een overzicht van de economische resultaten van de groep 'zeebaarsschepen'. Deze groep is gedefinieerd als schepen die tussen 2010 en 2016 minimaal 1 kilo zeebaars hebben aangeland. Bij elkaar gaat dit om 295 schepen (zie tabel 2). In de tabel staan per tuigcategorie de opbrengst, variabele kosten, vaste kosten en winst benoemd.

Tabel 1 Economische gegevens zeebaars schepen 2014 ( $\mathrm{mln} . €)$

\begin{tabular}{lrrrr} 
Categorie & Oplengst & Variabele kosten & Vaste kosten & 21,73 \\
Demersaal & 165,58 & 115,02 & 28,83 \\
\hline Flyshoot & 17,23 & 11,67 & 2,90 & 0,61 \\
\hline Lijnen & 1,34 & 0,52 & 0,41 \\
\hline Staand want & 2,02 & 1,32 & 0,50 & 0,20 \\
\hline Overig a) & 30,75 & 19,50 & 7,08 & 3,17 \\
\hline Totaal & 216,93 & 148,04 & 32,61 & 36,26 \\
\hline
\end{tabular}

a) De categorie 'overig' is zeer divers en wordt daarom in de economische analyse van de scenario's buiten beschouwing gelaten.

Bron: VIRIS en Bedrijveninformatienet.

Tabel 2 toont een overzicht van het aandeel van zeebaars in de totale opbrengst per tuigcategorie voor het jaar 2014. Net als in tabel 1 wordt hier gerekend met alle 'zeebaarsschepen'; dit zijn alle schepen die tussen 2010 en 2016 minimaal 1 kilo aan zeebaars hebben aangeland.

Tabel 2 Verdeling van aanlandingen en opbrengsten van zeebaars in 2014 per tuigcategorie door schepen die tussen 2010 en 2016 zeebaars aangeland hebben ('zeebaarsschepen')

\begin{tabular}{|c|c|c|c|c|}
\hline Categorie & $\begin{array}{l}\text { Aantal schepen die } \\
\text { zeebaars vangen }\end{array}$ & Vangst zeebaars ( $k g$ ) & Opbrengst zeebaars ( $€$ ) & $\begin{array}{l}\text { Aandeel zeebaars in } \\
\text { totale opbrengst }(\%)\end{array}$ \\
\hline Demersaal & 117 & 44.519 & 523.667 & 0,3 \\
\hline Flyshoot & 13 & 91.001 & 952.617 & 5,5 \\
\hline Lijnen & 80 & 81.423 & 1.130 .794 & 84,4 \\
\hline Staand want & 77 & 16.016 & 212.734 & 10,5 \\
\hline Overig a) & 21 & 3.073 & 47.386 & 0,2 \\
\hline Totaal & 295 & 236.032 & 2.867 .198 & 1,3 \\
\hline
\end{tabular}

a) De categorie 'overig' is zeer divers en wordt daarom in de economische analyse van de scenario's buiten beschouwing gelaten.

Bron: VIRIS en Bedrijveninformatienet. 
In figuur 1 staan de gegevens uit tabel 2 weergegeven.
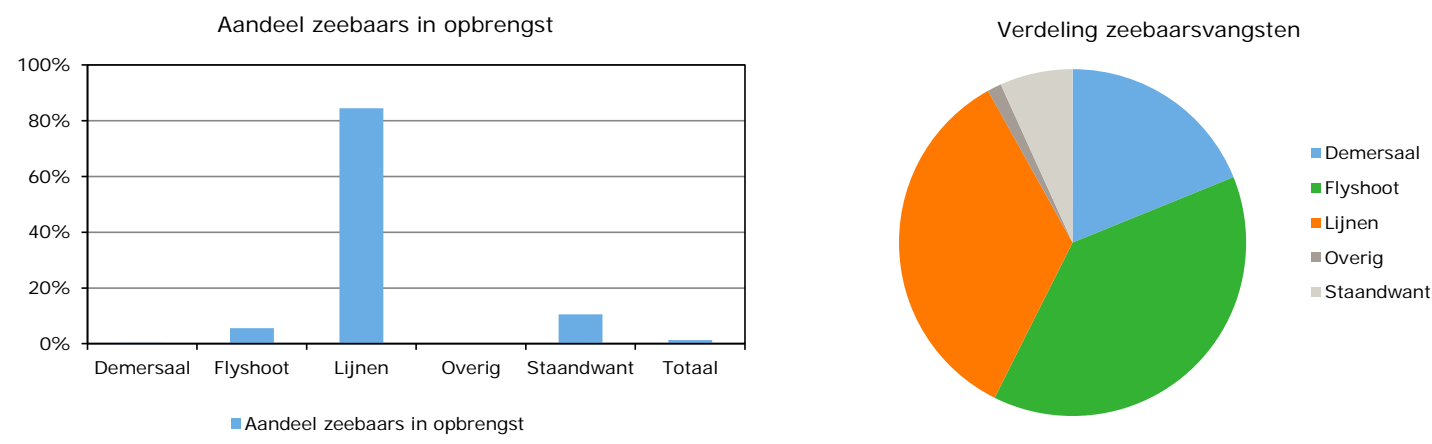

Figuur 1 Aandeel van zeebaars in de opbrengsten van de verschillende tuigcategorieën (links) en het aandeel van de verschillende tuigcategorieën in de totale zeebaarsvangst (rechts) (2014) Bron: VIRIS en Bedrijveninformatienet.

Het linkerdeel van figuur 1 toont het aandeel van zeebaars in de opbrengsten van de tuigen waarmee zeebaars wordt gevangen en aangeland. Hieruit blijkt, dat de lijnenvisserij verreweg het meest afhankelijk is van de zeebaars, op afstand gevolgd door de staandwant- en flyshootvisserij; voor de demersale visserij is dit $0,3 \%$. Het rechter deel van figuur 1 toont het aandeel van de tuigen in de totale zeebaars aanlandingen. Hieruit blijkt dat de flyshootvisserij verantwoordelijk is voor het grootste gedeelte van de zeebaars aanlandingen (39\%), gevolgd door de lijnenvisserij (35\%), demersale visserij (19\%) en staandwantvisserij (7\%).

\subsection{Historische ontwikkeling aanlandingen}

Figuur 2 toont de historische ontwikkeling van de aanlandingen van zeebaars in de Nederlandse beroepsvisserij van 2010 tot 2015. Tussen 2010 en 2015 zijn deze aanlandingen met 42\% afgenomen. De ontwikkeling in de aanlandingen verschilt sterk per tuigcategorie. Zo zijn de aanlandingen in de demersale visserij met $74 \%$ afgenomen. Voor de lijnen- en staandwantvisserij bedroeg deze afname respectievelijk $36 \%$ en $41 \%$. De aanlandingen van de flyshootvisserij zijn in 2015 ten opzichte van 2010 toegenomen maar ten opzichte van 2013 gedaald.

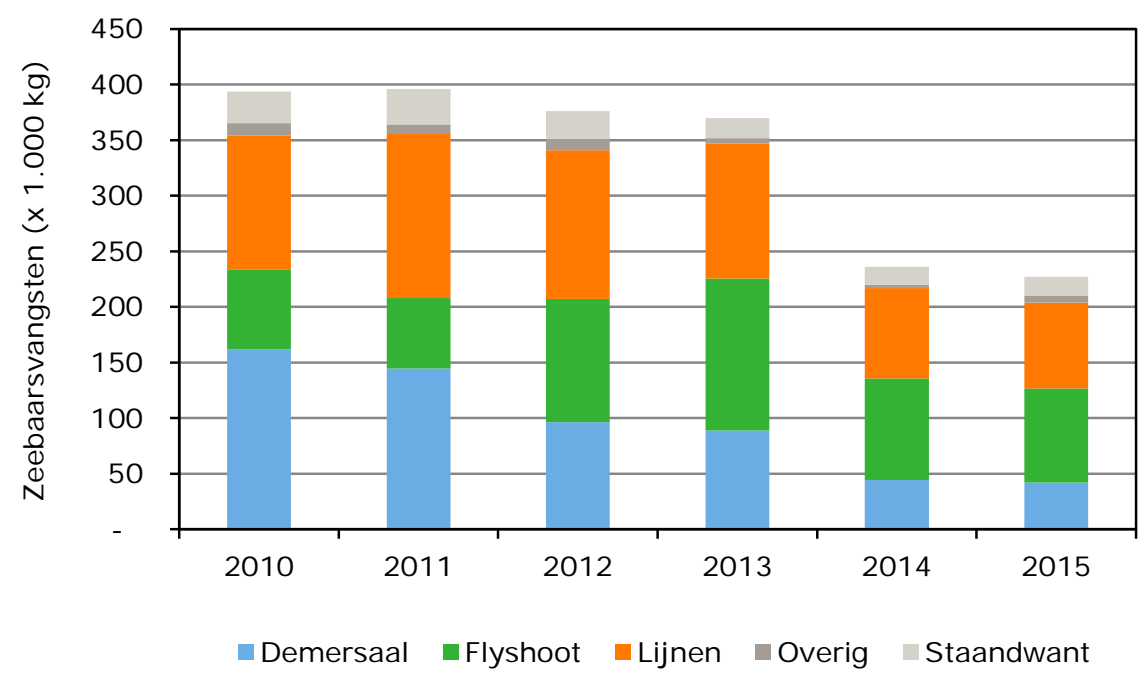

Figuur 2 Ontwikkeling aanlandingen zeebaars per tuigcategorie 2010-2015 Bron: VIRIS. 


\subsection{Maandelijkse aanlandingen zeebaarsvisserij}

De Nederlandse zeebaarsvisserij kent voor iedere vistuigcategorie duidelijke seizoenspatronen en verschillen in vangstgebieden. In figuur 3 staan voor 2015 de maandelijkse aanlandingen per tuigcategorie weergegeven:

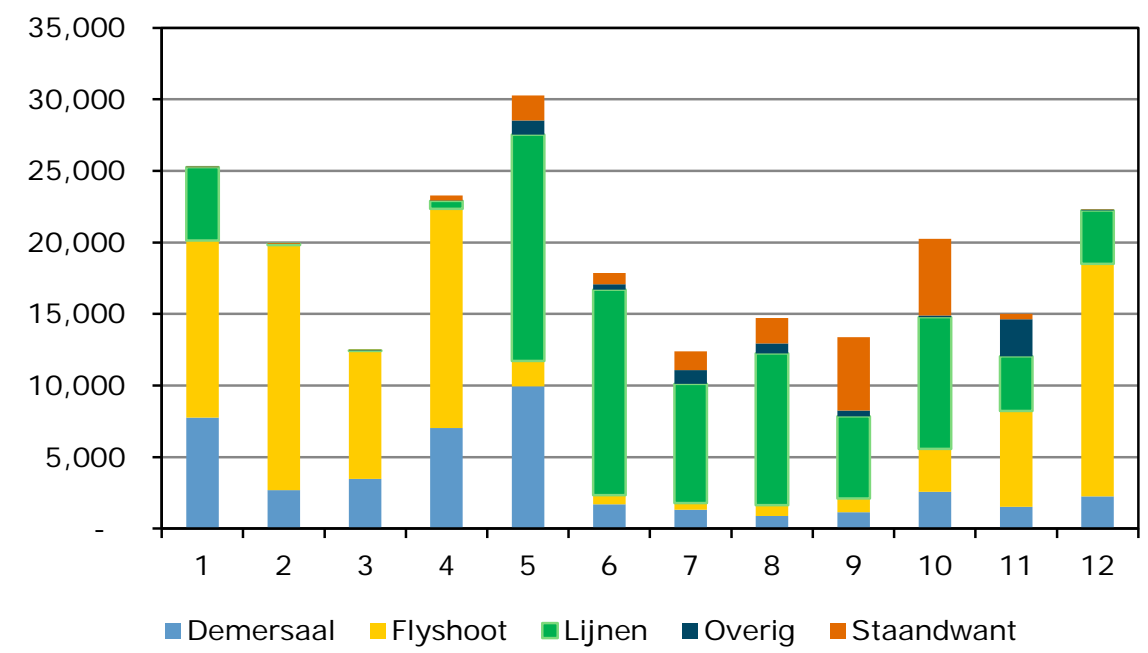

Figuur 3 De maandelijkse aanlandingen per tuigcategorie in 2015 Bron: VIRIS.

De piek in de flyshootvisserij in decemberi-april wordt gevormd door visserij in het Kanaal en komt overeen met het paaiseizoen van zeebaars in dit gebied; zie de (Engelstalige) figuur hieronder met daarin de paaiseizoenen per deelgebied in het Noordoostelijk deel van de Atlantische Oceaan.

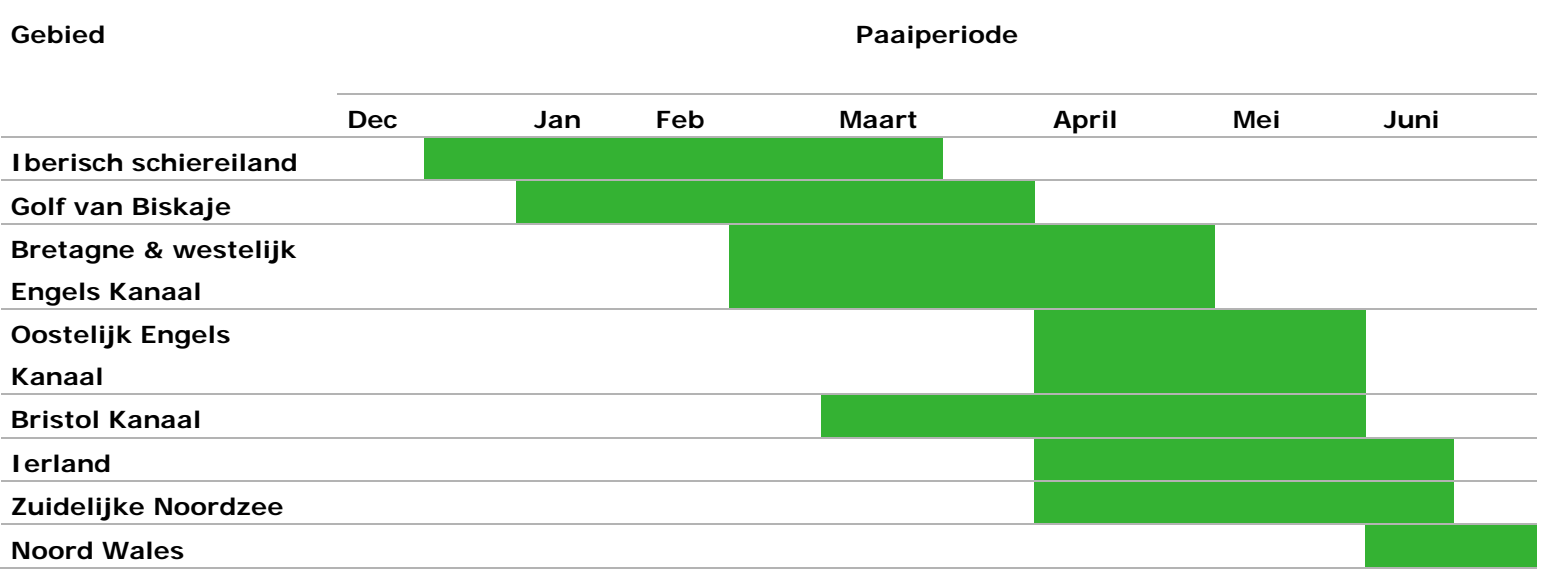

Figuur 4 Verloop van paaiactiviteit van zeebaars in het Noordoostelijk deel van de Atlantische Oceaan

Bron: Lopez et al. (2015).

De zeebaarsvisserij in het kanaal vormt samen met de Nederlandse kust een belangrijk herkomstgebied van de aangelande zeebaars. Zo is het kustgebied vooral van belang voorde handlijnen staandwant visserij. In de volgende paragraaf gaan we nader in op de ruimtelijke verdeling van de herkomst van de door de Nederlandse commerciële visserijvloot aangelande zeebaars. 


\subsection{Vangstgebieden aangelande zeebaars}

In figuur 5 (links) is de ruimtelijke verdeling van de herkomst (Noordzee en Kanaal) van alle aangelande zeebaars door de Nederlandse commerciële visserijvloot weergegeven. Alle kwadranten waar in 2014 meer dan $100 \mathrm{~kg}$ zeebaars werd gevangen zijn gemarkeerd. In figuur 5 (rechts) zijn de vijf kwadranten waarin de meeste aangelande zeebaars wordt gevangen uitgelicht. Deze kwadranten waren samen goed voor ca $75 \%$ van de aangelande zeebaars.
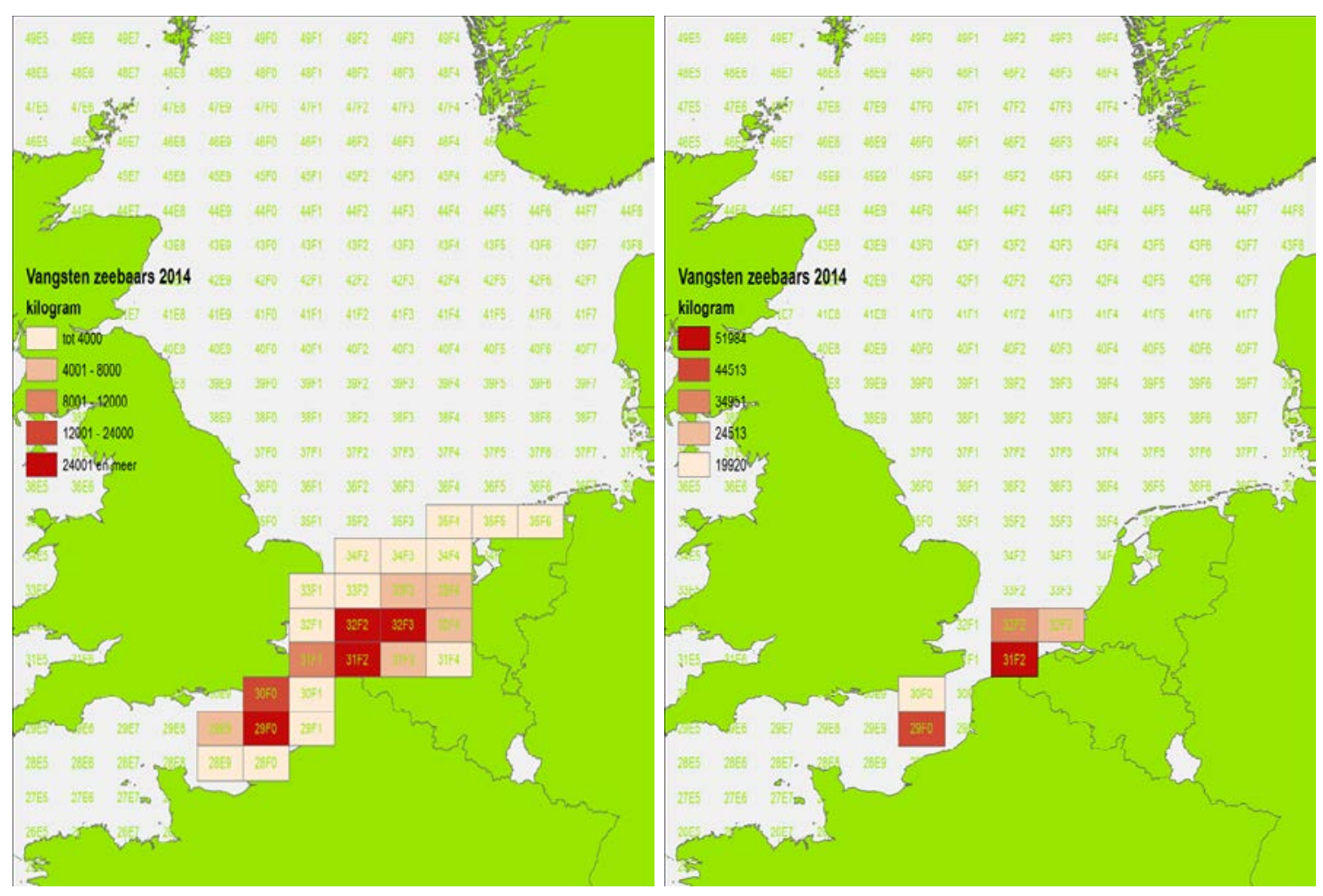

Figuur 5 Aangelande zeebaarsvangsten per ICES kwadrant en top 5 Zeebaarskwadranten Bron: VIRIS.

\subsection{Aanlandingen vanuit de recreatieve visserij}

In het ICES advies staat dat vangsten in de recreatieve visserij aangemerkt worden als substantieel maar dat deze niet precies gekwantificeerd kunnen worden. Er is ingeschat dat in 2012 de jaarlijkse vangsten (aanlandingen en teruggooi) door Frankrijk, Engeland, Nederland en België in totaal uitkwamen op 1500 ton. Andere inschattingen worden genoemd in van der Hammen en de Graaf (2015) en ICES (2015b); voor de Nederlandse recreatieve zeebaarsvisserij is deze in 2010-2011 ingeschat op 138 ton en in 2012-2013 op 229 ton (ICES 2015b Tabel 2; Van der Hammen en de Graaf 2015, tabel 4-7). In vergelijking met de commerciële zeebaarsvisserij in deze jaren van respectievelijk 395 en 376 ton in 2011 en 2012 betekent dit dat de recreatieve vangsten tussen de $26 \%$ en 38\% uitmaken van de totale aanlandingen. 


\section{Resultaten per scenario}

\subsection{Inleiding}

In dit hoofdstuk geven we de resultaten weer van de analyse naar de effecten in aanlandingen en opbrengsten van zeven mogelijke maatregelen (scenario's) die de visserij op zeebaars op verschillende manieren beperken:

\subsection{Scenario 1A: Volledig visverbod met alle tuigen die zeebaars vangen in alle kwadranten van waar nu zeebaars wordt aangeland ('zero catch')}

\subsubsection{Uitgangspunten en aannames}

- In dit scenario worden kwadranten van waaruit zeebaars wordt aangeland gesloten voor alle tuigen waarmee zeebaars wordt gevangen. Daarbij is een drempel van $100 \mathrm{~kg}$ per kwadrant gehanteerd. De kwadranten van waaruit minder dan $100 \mathrm{~kg}$ wordt aangeland blijven hierbij dus open;

- De in dit scenario te sluiten kwadranten worden getoond in figuur 3 (linker figuur).

\subsubsection{Resultaten analyse}

In figuur 6 geven we een overzicht van de effecten op de besomming en de winst per tuigcategorie:
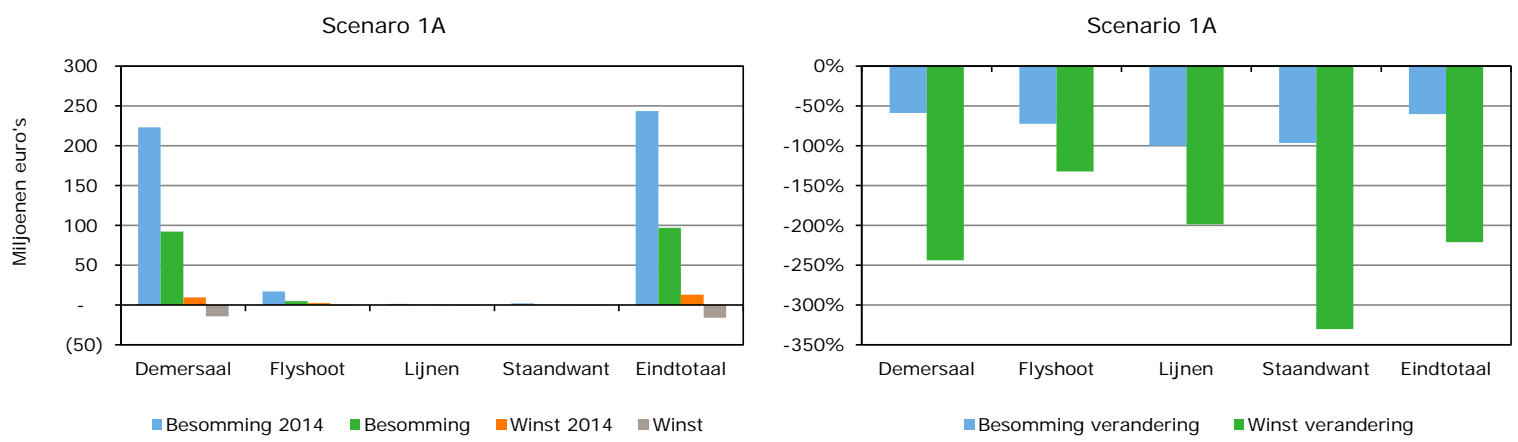

Figuur 6 Scenario 1A: effecten op besomming en winst per tuigcategorie ten opzichte van 2014 Bron: VIRIS en Bedrijveninformatienet.

Uit de analyse voor dit scenario kunnen de volgende conclusies worden getrokken:

- In dit scenario wordt het ICES advies 'zero catch' bijna volledig opgevolgd. De zeebaars aanlandingen bedragen slechts 0,2\% van die in 2014 .

- Omdat het visverbod geldt voor alle tuigen die in principe zeebaars kunnen vangen wordt een grotere groep schepen getroffen dan alleen de schepen die in de afgelopen jaren ook daadwerkelijk zeebaars hebben aangeland ('zeebaarsschepen').

- De besomming van lijnen en staandwantvisserij daalt bij gelijkblijvende kosten met bijna 100\%, die van de demersale en flyshoot visserij met 59\% respectievelijk $72 \%$.

- Voor de lijnen, staand want, flyshoot en demersale visserij samen daalt de besomming in dit scenario bij gelijkblijvende kosten met circa 147 miljoen euro (ruim 60\%) en de winst met 28 miljoen euro $(221 \%)$. 


\subsection{Scenario 1B: Aanlandverbod voor zeebaars uit kwadranten van waaruit nu zeebaars wordt gevist en aangeland}

\subsubsection{Uitgangspunten en aannames}

- In dit scenario mag geen zeebaars worden aangeland uit de gebieden waar nu zeebaars wordt gevangen en aangeland. Daarbij is een drempel van $100 \mathrm{~kg}$ gehanteerd. De kwadranten van waaruit minder dan $100 \mathrm{~kg}$ wordt aangeland blijven dus open;

- Het gaat hier om dezelfde kwadranten als in scenario 1A (zie figuur 2 (links));

- Een aanlandverbod betekent dat de zeebaars wordt vermeden of teruggegooid. Dit geldt ook voor de andere scenario's $(2,3,4,5 \mathrm{~B})$ waar een aanlandverbod geldt;

- Visserijactiviteiten blijven gelijk aan die in het basisjaar (2014). Alle kosten blijven dus ook gelijk;

- De opbrengsten worden verminderd met de opbrengsten van de zeebaars die door deze maatregel niet meer mag worden aangeland

\subsubsection{Resultaten analyse}

Figuur 7 geeft een overzicht van de effecten op de besomming en de winst per tuigcategorie.
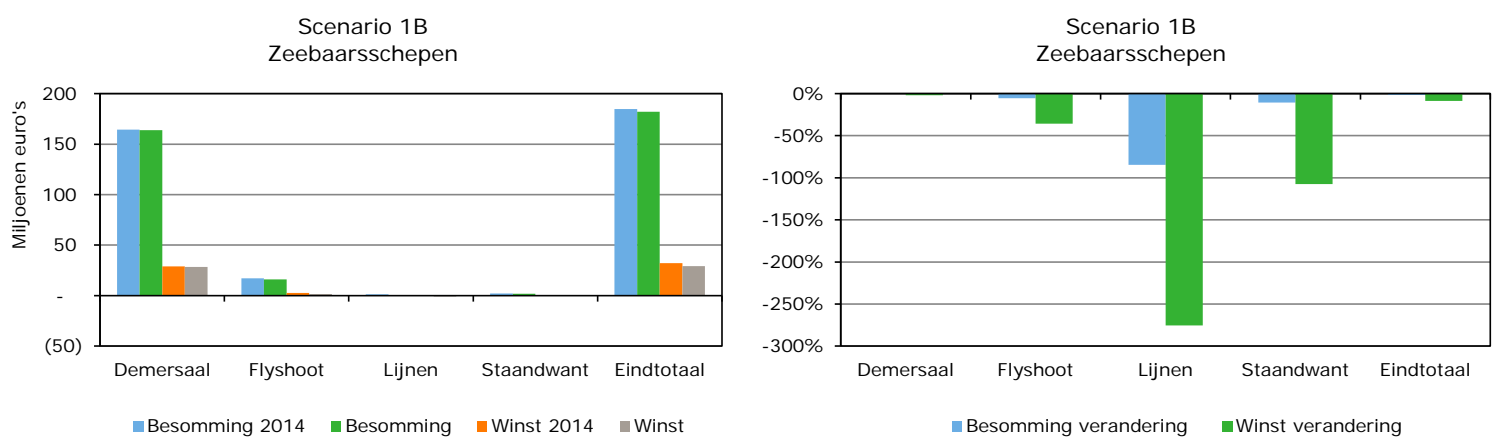

Figuur 7 Scenario 1B: effecten op de besomming en winst per tuigcategorie ten opzichte van 2014

Bron: VIRIS en Bedrijveninformatienet.

Uit de analyse voor dit scenario kunnen de volgende conclusies worden getrokken:

- Ook in dit scenario worden de aanlandingen van zeebaars teruggebracht tot 0,2\% van die in 2014. Door deze maatregel worden alleen de schepen getroffen die ook daadwerkelijk zeebaars aanlanden.

- Omdat er wel wordt gevist in gebieden van waaruit normaal gesproken zeebaars wordt aangeland, is niet bekend of de zeebaars wordt vermeden of wordt gevangen en teruggegooid.

- De besomming en winst van de lijnen, staand want, flyshoot en demersale visserij daalt bij gelijkblijvende kosten met circa 2,8 miljoen euro. Voor de zeebaarsschepen betekent dit een daling van de besomming met $1,5 \%$ en van de winst met bijna $9 \%$. Er zijn echter grote verschillen tussen de verschillende vistuigcategorieën:

- De lijnenvisserij wordt verreweg het zwaarst getroffen door deze maatregel (daling besomming met $85 \%$ en winst met $275 \%$ ), gevolgd door de staandwant visserij (besomming $-11 \%$, winst $108 \%$ ). De flyshootvisserij wordt slechts licht getroffen.

- Voor de lijnen en staandwant visserij wordt de winst in dit scenario negatief. De demersale visserij ondervindt nauwelijks negatieve effecten van deze maatregel. 


\subsection{Scenario 2: Aanlandverbod voor het hele jaar voor zeebaars voor alle tuigen behalve lijnen en staandwant}

\subsubsection{Uitgangspunten en aannames}

- De visserijactiviteiten veranderen niet, alleen wordt nu de zeebaars door de flyshoot en demersale visserij vermeden of teruggegooid;

- Alle kosten blijven gelijk;

- De opbrengsten van de flyshoot en demersale visserij worden verminderd met de opbrengsten van zeebaars.

\subsubsection{Resultaten analyse}

Figuur 8 geeft een overzicht van de effecten op de besomming en de winst per tuigcategorie.
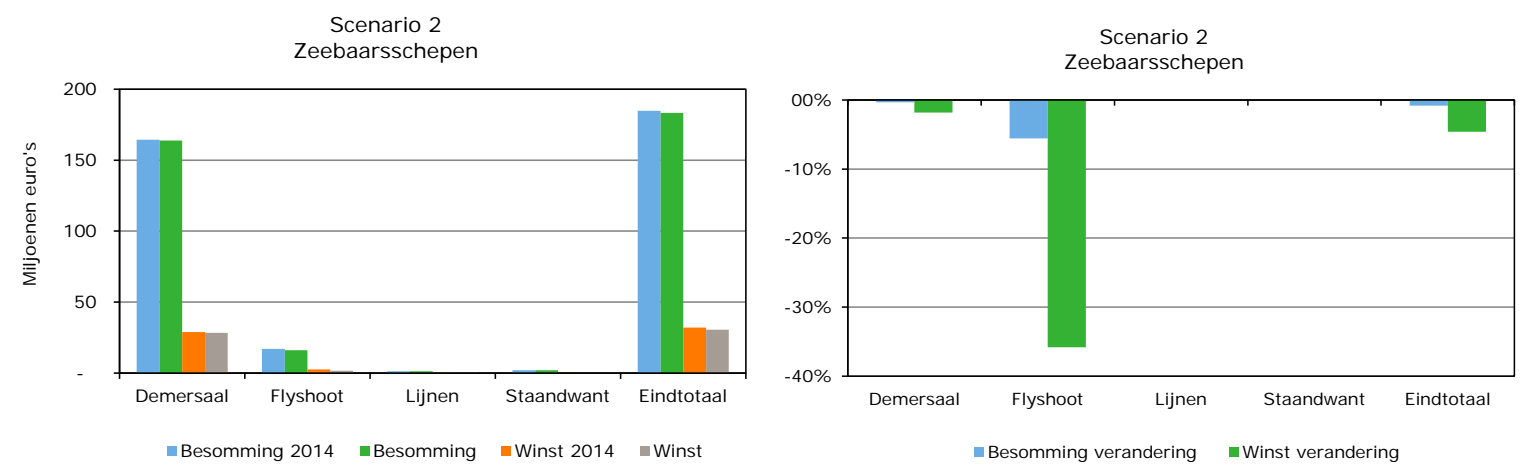

Figuur 8 Scenario 2: effecten op besomming en winst per tuigcategorie ten opzichte van 2014 Bron: VIRIS en Bedrijveninformatienet.

Uit de analyse voor dit scenario kunnen de volgende conclusies worden getrokken:

- In dit scenario dalen de zeebaars aanlandingen tot ruim 97 ton. Dat is $41 \%$ van het niveau in 2014 .

- De besomming en winst van de lijnen, staand want, flyshoot en demersale visserij samen dalen met bijna 1,5 miljoen euro.

- Met een winstdaling van 36\% wordt de Flyshoot visserij in dit scenario het zwaarst getroffen. De winst voor deze schepen blijft wel positief. De winst van de zeebaarsschepen met demersale tuigen daalt met ongeveer $2 \%$ ten opzichte van 2014.

- De lijnen en staandwantvisserij worden uiteraard niet geraakt door deze maatregel.

- NB: het effect van de teruggooi op de populatie hangt sterk af van de overlevingskansen. 


\subsection{Scenario 3: Aanlandverbod voor het hele jaar voor zeebaars voor alle tuigen behalve flyshoot en gesleepte tuigen (demersaal)}

\subsubsection{Uitgangspunten en aannames}

- De visserijactiviteiten veranderen niet. Alleen wordt nu door de lijnen en staandwantvisserij de zeebaars vermeden of teruggegooid;

- Alle kosten blijven gelijk;

- De opbrengsten van de lijnen en staandwantvisserij worden verminderd met de opbrengsten van zeebaars die door deze maatregel niet meer mag worden aangeland.

\subsubsection{Resultaten analyse}

Figuur 9 geeft een overzicht van de effecten op de besomming en de winst per tuigcategorie.
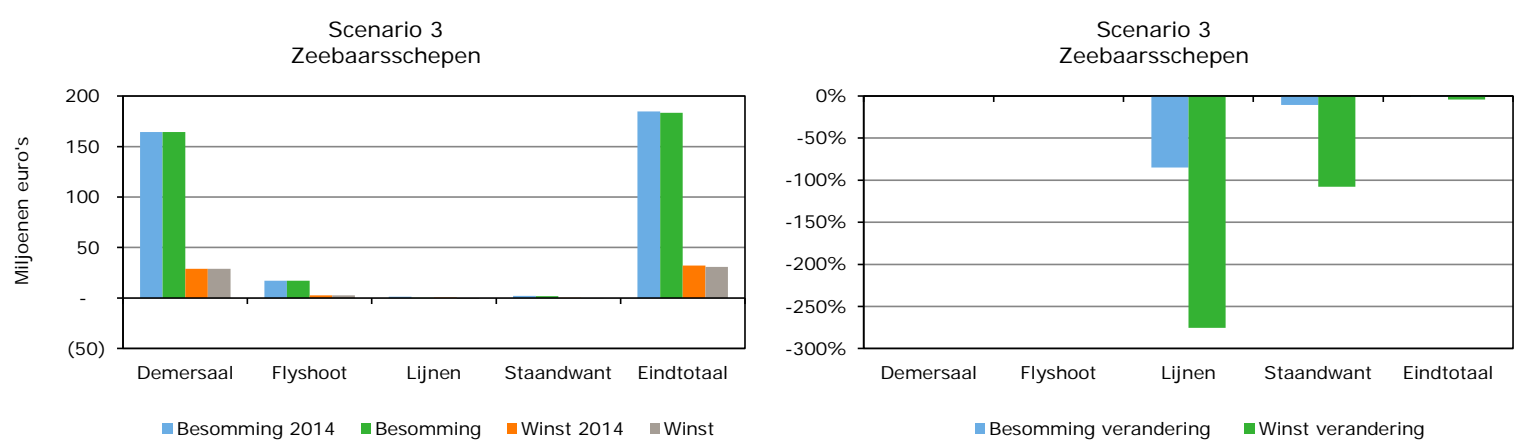

Figuur 9 Scenario 3: effecten op besomming en winst per tuigcategorie ten opzichte van 2014 Bron: VIRIS en Bedrijveninformatienet.

Uit de analyse voor dit scenario kunnen de volgende conclusies worden getrokken:

- In dit scenario dalen de zeebaars aanlandingen tot ruim 135 ton (57\% van de aanlandingen in 2014)

- De besomming en winst van de lijnen, staand want, flyshoot en demersale visserij samen dalen met ruim 1,3 miljoen euro.

- De lijnenvisserij wordt verreweg het zwaarst getroffen met een daling van de besomming met $85 \%$ en van de winst met $275 \%$. De besomming van de staandwantvisserij daalt met $11 \%$ en de winst met meer dan $100 \%$.

- De maatregel heeft uiteraard geen effect op de demersale visserij en de flyshootvisserij

- NB: het effect van de teruggooi op de populatie hangt sterk af van de overlevingskansen 


\subsection{Scenario 4: Aanlandverbod voor het hele jaar voor zeebaars voor alle tuigen. Voor lijnen en staand want is het alleen in februari en maart verboden om zeebaars aan te landen en geldt voor de rest van het jaar een maximum van $1.000 \mathrm{~kg}$ per schip per maand}

\subsubsection{Uitgangspunten en aannames}

- Omdat lijnen en staand want gemiddeld 1.150 respectievelijk 250 kilo zeebaars per jaar per schip aanlanden en er maar enkele schepen zijn die in een enkele maand de $1.000 \mathrm{~kg}$ overschrijden (data 2014) is hier verondersteld dat $1.000 \mathrm{~kg}$ per maand per schip geen beperking vormt. Daardoor zijn de resultaten van dit scenario vrijwel gelijk aan die van scenario 2 .

\subsubsection{Resultaten analyse}

In figuur 10 geven we een overzicht van de effecten op de besomming en de winst per tuigcategorie:
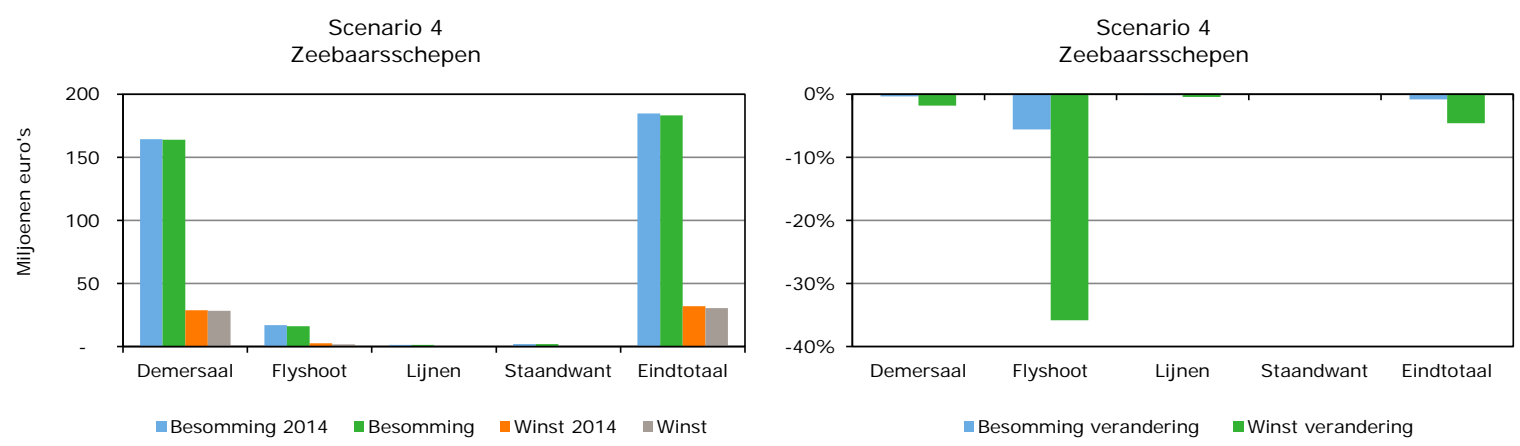

Figuur 10 Scenario 4: effecten op besomming en winst per tuigcategorie ten opzichte van 2014 Bron: VIRIS en Bedrijveninformatienet.

Uit de analyse voor dit scenario kunnen de volgende conclusies worden getrokken:

- In dit scenario dalen de aanlandingen van zeebaars door de Nederlandse vloot tot ruim 95 ton (41\% van het niveau van 2014).

- De besomming en winst van de lijnen, staandwant, flyshoot en demersale visserij samen dalen met ruim 1,5 miljoen euro.

- De flyshoot visserij wordt het zwaarst getroffen door deze maatregel. De besomming daalt met $6 \%$ en de winst met $36 \%$. De winst van de demersale visserij daalt met $2 \%$ terwijl de besomming slechts met $0,3 \%$ daalt.

- De lijnen en staandwantvisserij worden nauwelijks door deze maatregel geraakt omdat in februari en maart zeer weinig zeebaars wordt gevangen en aangeland en omdat slechts zelden door een schip meer dan $1000 \mathrm{~kg}$ per maand wordt aangeland. 


\subsection{Scenario 5a: Visverbod voor het hele jaar voor alle tuigen die zeebaars vangen (flyshoot, lijnen, staandwant, demersaal en overig) in die kwadranten van waaruit nu het meeste zeebaars wordt aangeland (tot circa $75 \%$ van de huidige aanlandingen)}

\subsubsection{Uitgangspunten en aannames}

- In scenario 5A worden 5 kwadranten van waruit in 2014 75\% van de zeebaars werd aangeland gesloten voor alle tuigen waarmee zeebaars wordt gevangen. De vijf te sluiten kwadranten zijn weergegeven in figuur 5 (rechts) (hoofdstuk 3). Vanuit de andere kwadranten mag dus wel zeebaars worden aangeland.

\subsubsection{Resultaten analyse}

In figuur 11 geven we een overzicht van de effecten op de besomming en de winst per tuigcategorie:
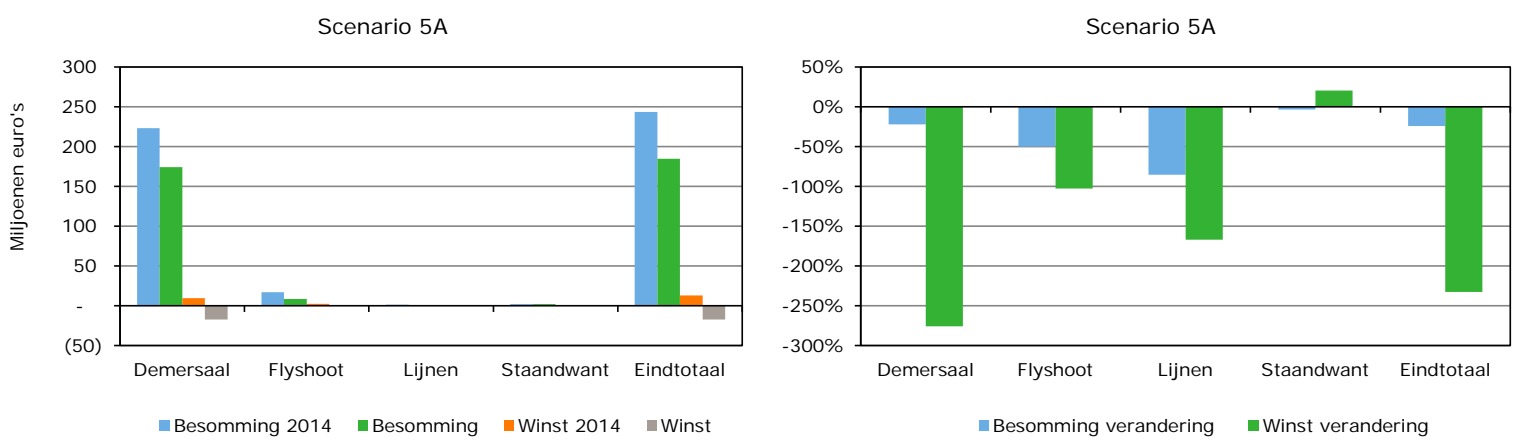

Figuur 11 Scenario 5A: effecten op besomming en winst per tuigcategorie ten opzichte van 2014 Bron: VIRIS en Bedrijveninformatienet.

Uit de analyse voor dit scenario kunnen de volgende conclusies worden getrokken:

- In dit scenario dalen de aanlandingen van zeebaars tot ca 60 ton, 25\% van het niveau van 2014.

- Omdat in dit scenario een visverbod in de betreffende kwadranten geldt voor schepen die met tuigen vissen waarmee zeebaars kan worden gevangen, worden net als in scenario 1A ook de schepen die in het verleden met deze tuigen geen zeebaars vingen door deze maatregel geraakt.

- De besomming en winst van de lijnen, staand want, flyshoot en demersale visserij samen dalen met respectievelijk 59 miljoen euro en 30 miljoen euro.

- De lijnen-, flyshoot- en demersale visserij worden in dit scenario sterk beïnvloed:

- De besomming van de lijnenvisserij daalt met $85 \%$ en de winst daalt met $167 \%$ en slaat dus om in een substantieel verlies.

- De besomming van de flyshoot visserij daalt met $50 \%$ en de winst met $103 \%$.

- De besomming van de demersale visserij neemt met $22 \%$ af en de winst die oorspronkelijk $4 \%$ van de opbrengst bedroeg slaat om in een fors verlies van ongeveer $10 \%$ van de opbrengst.

- De besomming van de staandwantvisserij neemt slechts met $3 \%$ af en de winst stijgt zelfs met 13\%. De activiteiten buiten de gesloten kwadranten zijn voor deze schepen winstgevender dan die erbinnen. De aanlandingen van zeebaars door staandwant schepen komen ook grotendeels uit andere kwadranten dan de kwadranten die in dit scenario worden gesloten. 


\subsection{Scenario 5b: Aanlandverbod voor zeebaars gedurende het hele jaar in die kwadranten van waaruit nu het meeste zeebaars aangeland wordt}

\subsubsection{Uitgangspunten en aannames}

- De kwadranten van waaruit het meeste wordt aangeland zijn in dit geval de kwadranten van waaruit tot circa $75 \%$ van de huidige aanlandingen afkomstig zijn.

- Er wordt nog steeds gevist in de 5 kwadranten waar het aanlandverbod geldt maar de zeebaars wordt vermeden of overboord gezet. In de overige kwadranten mag wel zeebaars gevangen worden.

- Visserijactiviteiten veranderen niet.

\subsubsection{Resultaten analyse}

In figuur 12 geven we een overzicht van de effecten op de besomming en de winst per tuigcategorie:
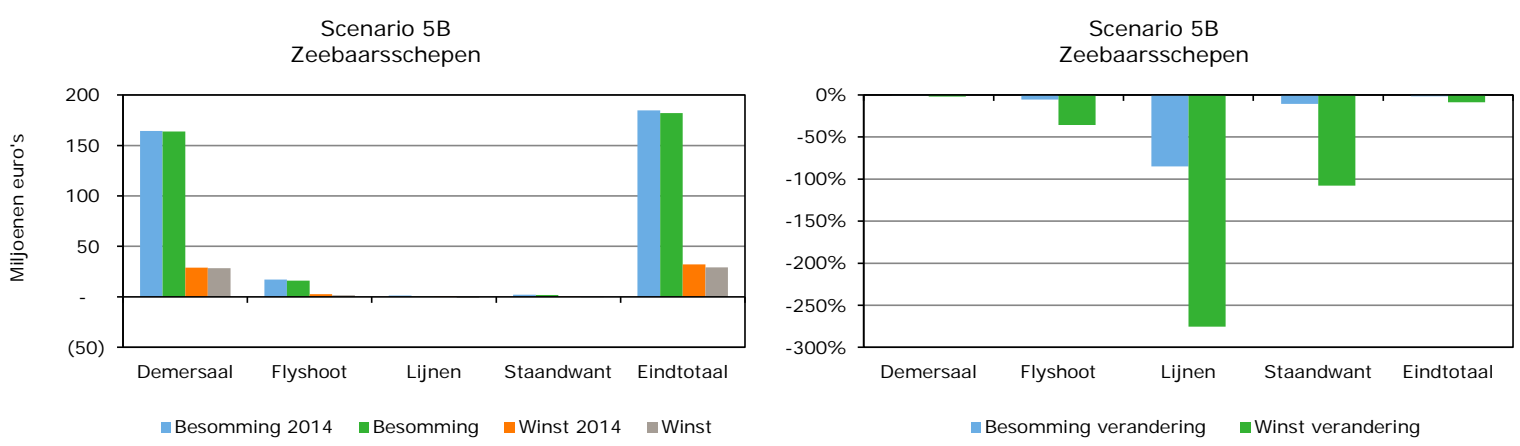

Figuur 12 Scenario 5B: effecten op besomming en winst per tuigcategorie ten opzichte van 2014 Bron: VIRIS en Bedrijveninformatienet.

\section{Conclusies}

- De zeebaarsaanlandingen dalen tot $25 \%$ van het niveau van 2014 , circa 60 ton.

- De besomming en winst van de lijnen, staandwant, flyshoot en demersale visserij samen dalen met 2,1 miljoen euro.

- De lijnenvisserij wordt het sterkste beïnvloed (besomming -72\%, winst -235\%), gevolgd door de flyshoot visserij (besomming $-4 \%$, winst $-28 \%$ ). De besomming van de staandwantvisserij daalt met $1 \%$ en de winst met $7 \%$.

- De schepen met demersaal tuig worden slechts licht beïnvloed. De besomming daalt voor deze categorie met $0,2 \%$ en de winst met $1,3 \%$. 


\section{$4 \quad$ Samenvattend overzicht effecten alle scenario's}

\subsection{Inleiding}

In dit hoofdstuk geven we een synthese van de effecten van alle scenario's. Hiermee maken we overzichtelijk hoe de verschillende scenario's zich tot elkaar verhouden qua effecten op aanlandingen en economische opbrengsten voor de verschillende vistuigcategorieën.

\subsection{Aanlandingen zeebaars per scenario}

In figuur 13 geven we per scenario de verwachte hoeveelheid aanlandingen weer. In tabel 3 staan deze aanlandingen als percentage van de aanlandingen zoals die in 2014 gerapporteerd zijn.

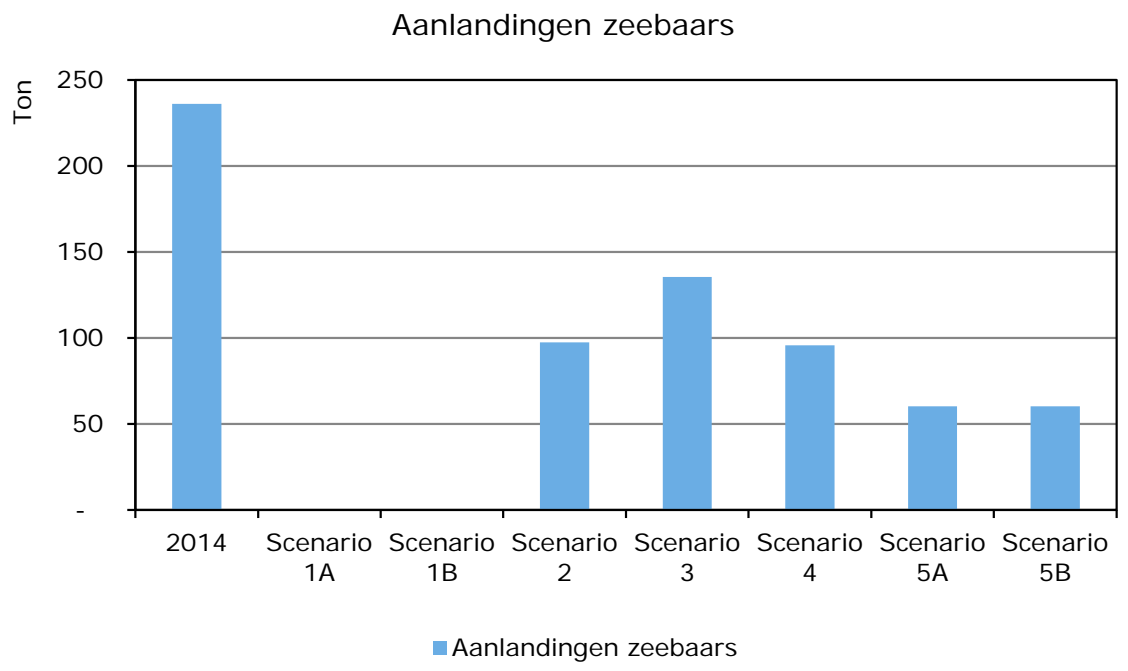

Figuur 13 Aanlandingen zeebaars 2014 per scenario Bron: VIRIS en Bedrijveninformatienet.

Tabel 3 Aanlandingen zeebaars per scenario

\begin{tabular}{|c|c|c|}
\hline Categorie & Aanlandingen zeebaars (ton) & Aanlandingen zeebaars ( $\%$ 2014) \\
\hline 2014 & 236,032 & \\
\hline Scenario $1 \mathrm{~A}$ & 408 & 0,2 \\
\hline Scenario 1B & 408 & 0,2 \\
\hline Scenario 2 & 97.439 & 41 \\
\hline Scenario 3 & 135,520 & 57 \\
\hline Scenario 4 & 95,701 & 41 \\
\hline Scenario 5A & 60,151 & 25 \\
\hline Scenario 5B & 60,151 & 25 \\
\hline
\end{tabular}

Bron: VIRIS en Bedrijveninformatienet. 
Uit figuur 13 en tabel 3 blijkt, dat de verwachte aanlandingen per scenario sterk verschillen:

- De aanlandingen dalen uiteraard het meest in scenario 1 ('zero catch'). In scenario 3 dalen de aanlandingen het minst ten opzichte van 2014 ( $57 \%$ van de aanlandingen; een daling van 43\%).

- In scenario 1A en 5A betekent de reductie van aanlandingen waarschijnlijk ook een reductie van de vangst van zeebaars in dezelfde mate omdat hier een visverbod geldt voor de kwadranten waar (veel) zeebaars wordt gevangen. In de overige scenario's wordt de reductie van aanlandingen bereikt door een aanlandverbod.

- Naleving van het aanlandverbod kan betekenen dat de zeebaars wordt vermeden maar ook dat de zeebaars overboord wordt gezet. In het laatste geval zal de effectiviteit van de maatregel afhankelijk zijn van de mate waarin de zeebaars het teruggooien overleeft. Om de effectiviteit van deze maatregelen te bepalen zal dus nader onderzoek nodig zijn naar de overleving van zeebaars in de verschillende tuigcategorieën.

- Tegenover de grotere zekerheid die scenario 1A en 5A bieden ten aanzien van de reductie van de vangsten staat wel een veel grotere daling van inkomsten voor de vloot dan in de overige scenario's.

In tabel 4 staat een overzicht van de besomming en winst voor de lijnen, staand want, flyshoot en demersale visserij in de verschillende scenario's gerelateerd aan de reductie in aanlandingen die wordt bereikt. Hieruit blijkt, dat in scenario $1 \mathrm{~A}$ voor elke $\mathrm{kg}$ reductie in de aanlanding van zeebaars 623 euro aan besomming ingeleverd en 122 euro aan winst. In scenario 5A is dit respectievelijk 334 en 172 euro per kilo zeebaars. In de overige scenario's liggen de daling van besomming en winst per kg zeebaars in de orde van de verkoopprijs van zeebaars (bij verkoop na aanlanding). De verdelingseffecten over de verschillende tuigcategorieën verschillen natuurlijk wel sterk voor de verschillende scenario's.

Tabel 4 Economische effecten op de zeebaarsschepen per scenario ( $\mathrm{mln} . €)$

\begin{tabular}{|c|c|c|c|c|}
\hline Categorie & $\begin{array}{l}\text { Aanlandingen } \\
\text { zeebaars ( kg) }\end{array}$ & $\begin{array}{r}\text { Aanlandingen als \% } \\
\text { van } 2014\end{array}$ & $\begin{array}{l}\text { Verandering totale } \\
\text { besomming ( } \mathrm{m} / \mathrm{n}, €) \text { a) }\end{array}$ & $\begin{array}{r}\text { Verandering } \\
\text { winst }(\mathrm{m} / \mathrm{n}, €) \text { a) }\end{array}$ \\
\hline Scenario $1 \mathrm{~A}$ & 408 & 0,2 & $-146,72$ & $-28,82$ \\
\hline Scenario 2 & 97.439 & 41,3 & $-1,48$ & $-1,48$ \\
\hline Scenario 3 & 135.520 & 57,4 & $-1,34$ & $-1,34$ \\
\hline Scenario 5A & 60.151 & 25,5 & $-58,75$ & $-30,33$ \\
\hline Scenario 5B & 60.151 & 25,5 & $-2,11$ & $-2,11$ \\
\hline
\end{tabular}

a) Het betreft hier de verandering in de besomming en winst van alle schepen samen die met lijnen, staand want, flyshoot en demersale tuigen vissen.

Bron: VIRIS en Bedrijveninformatienet. 


\section{$5 \quad$ Analyse betrokken schepen}

\section{$5.1 \quad$ Inleiding}

Waar we in de vorige hoofdstukken de effecten per scenario op de verschillende tuigcategorieën geanalyseerd hebben, gaan we in dit hoofdstuk nader in op de schepen die binnen deze vistuigcategorieën vallen. De achtergrond van deze nadere analyse is dat de aanlandingen per categorie niet gelijkmatig verdeeld zijn; het ene schip landt immers meer zeebaars aan dan het andere schip en in het ene seizoen of gebied meer dan het andere.

\subsection{Schepen verantwoordelijk voor $80 \%$ van de aanlandingen}

Tussen 2010 en 2016 waren er 295 schepen met 1 of meer zeebaarsaanlandingen. In 2014 vingen 247 van deze schepen ook daadwerkelijk zeebaars. Hiervan hebben 39 schepen $(=16 \%)$ samen ongeveer $80 \%$ van de zeebaars aangeland. Deze 39 schepen landen elk $1.800 \mathrm{~kg}$ zeebaars aan per jaar of meer. Voor deze schepen maakt de zeebaars gemiddeld $6 \%$ van hun besomming uit. Voor lijnen en staand want ligt dit percentage echter veel hoger. In tabel 5 staat het overzicht van de schepen die in 2014 80\% van de zeebaars hebben aangeland.

Tabel 5 Overzicht van schepen die in 2014 80\% van de zeebaars hebben aangeland

\begin{tabular}{|c|c|c|c|c|c|}
\hline Categorie & Schepen a) & $\begin{array}{l}\text { Zeebaars- } \\
\text { aanlandingen }\end{array}$ & $\begin{array}{l}\text { Opbrengst } \\
\text { zeebaars }\end{array}$ & $\begin{array}{l}\text { Totale opbrengst } \\
\text { b) }\end{array}$ & $\begin{array}{l}\text { Percentage zeebaars } \\
\text { in besomming }\end{array}$ \\
\hline Demersaal & 7 & 29.707 & 338.017 & 19.961 .808 & 2 \\
\hline Lijnen & 18 & 66.027 & 910.782 & 926.384 & 98 \\
\hline Staand want & 2 & 4.114 & 49.399 & 107.267 & 46 \\
\hline Percentage & $16 \%$ & $80 \%$ & $78 \%$ & $25 \%$ & $\begin{array}{l}\text { percentage van de } \\
\text { besomming van de } \\
\text { schepen die in } 2014 \\
\text { zeebaars hebben } \\
\text { aangeland }\end{array}$ \\
\hline
\end{tabular}

a) Sommige schepen vissen met meerdere tuigen. Deze zijn hier ingedeeld bij het tuig waar ze het meest zeebaars mee vangen; b) Het betreft hier de verandering in de besomming en winst van alle schepen samen die met lijnen, staand want, flyshoot en demersale tuigen vissen. Bron: VIRIS en Bedrijveninformatienet.

In de volgende paragrafen zoomen we verder in op de aanlandingen van de schepen in de verschillende vistuigcategorieën. 


\subsection{Aanlandingen staandwantvisserij}

In figuur 14 staan de aanlandingen van alle staandwantschepen die in 2015 meer dan 30 kilo aanlandden. Deze aanlandingen zijn per schip gerangschikt naar afnemende aanlandingen. In 2015 waren er in totaal 60 staandwantschepen die zeebaars hebben aangeland. Uit de grafiek blijkt dat er hiervan 20 schepen waren die 100 kilo of meer aanlandden.

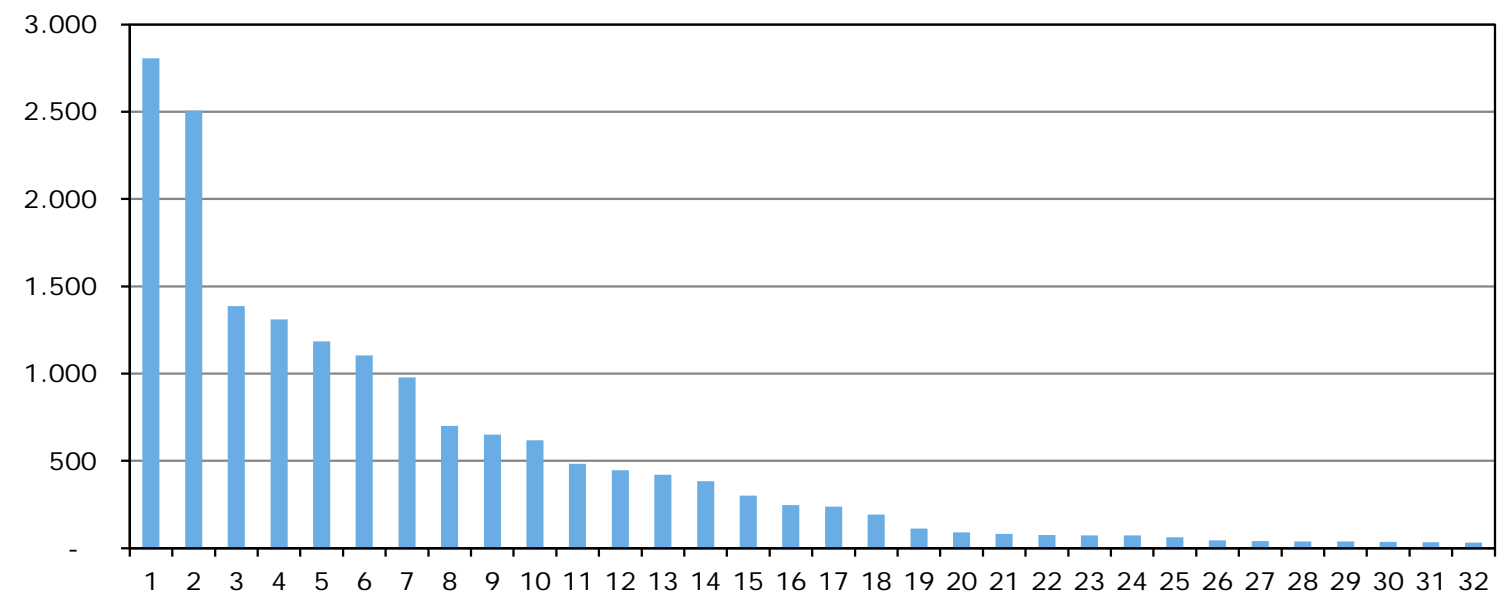

Figuur 14 Staandwantschepen die in 2015 in totaal meer dan 30 kg zeebaars aanlandden, gerangschikt naar aanlandingen van zeebaars in kilo's Bron: VIRIS.

Kijken we naar de vangsten per maand, dan valt op dat er 11 schepen in één of meer maanden in 2015 meer dan $250 \mathrm{~kg}$ hebben aangeland (hiervan is geen figuur in deze rapportage opgenomen). Aanlandingen boven de $250 \mathrm{~kg}$ kwamen alleen voor in de maanden mei en juli-oktober. Voor de meeste van deze 11 schepen gaat het om kleine overschrijdingen (van enkele tientallen of honderden kilo's) in één of twee maanden. Slechts twee schepen hadden elk in één maand rond de 1.200 kilo overschrijding. Een eventuele aanlandingsbeperking van $250 \mathrm{~kg}$ per maand zou in 2015 een aanlandingsreductie van $6.004 \mathrm{~kg}$ hebben betekend. Dit is ongeveer 35\% van de aanlandingen.

In de onderstaande figuur (figuur 15) is het aandeel zeebaars in de totale opbrengsten gerangschikt van hoog naar laag (omdat alleen van 2014 de economische gegevens beschikbaar zijn is er voor dit jaar gekozen). Hieruit blijkt, dat voor 22 schepen zeebaars meer dan $50 \%$ van hun totale opbrengsten uitmaakte. Hierbij moet wel opgemerkt worden dat deze opbrengsten sterk verschillen. Zo vormt voor de eerste 4 schepen in de grafiek zeebaars 100\% van de opbrengst maar is de opbrengst zelf in absolute zin relatief laag (zie de groene lijn onderin de grafiek, die de opbrengst weergeeft). 


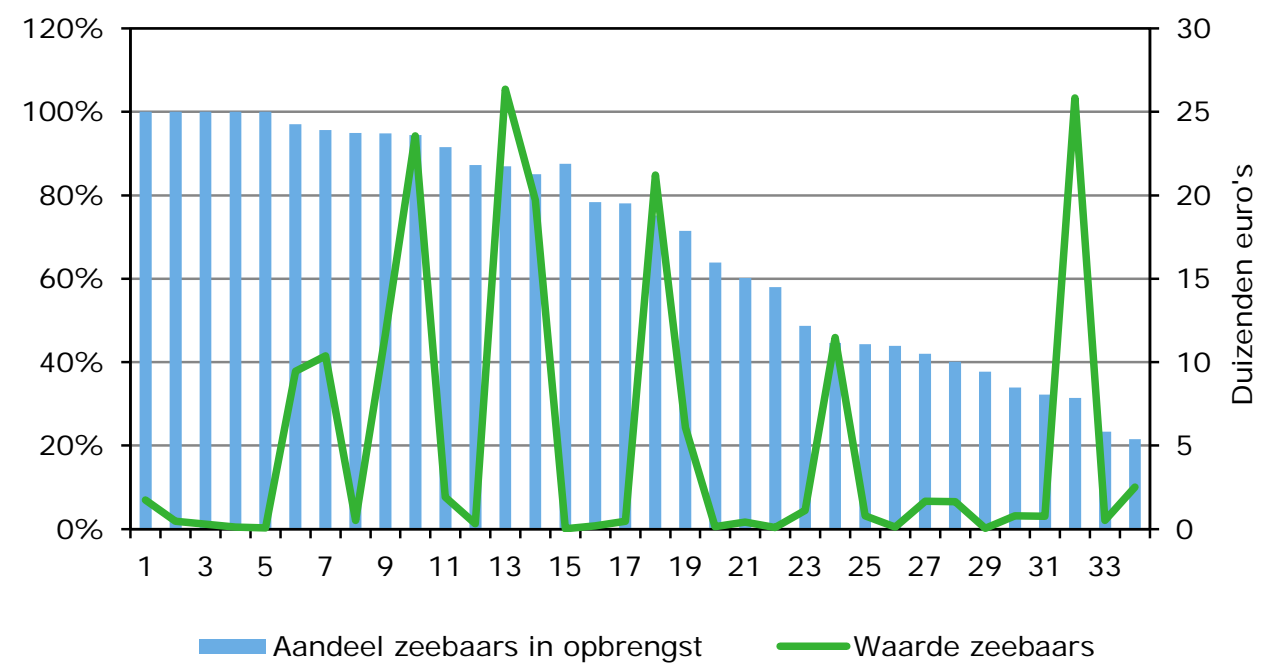

Figuur 15 Staandwantschepen gerangschikt naar het aandeel van zeebaars in totale opbrengst (2014)

Bron: VIRIS en Bedrijveninformatienet.

\subsection{Aanlandingen lijnenvisserij}

In 2015 waren er 76 schepen in de lijnenvisserij die zeebaars hebben aangeland. Hiervan landden 37 schepen meer dan $400 \mathrm{~kg}$ zeebaars aan. Deze aanlandingen zijn in figuur 16 gerangschikt naar afnemende aanlandingen. Uit deze figuur blijkt, dat 22 schepen meer dan $1000 \mathrm{~kg}$ hebben aangeland en geen van allen meer dan $10.000 \mathrm{~kg}$ (het maximum is ruim $8.500 \mathrm{~kg}$ ).

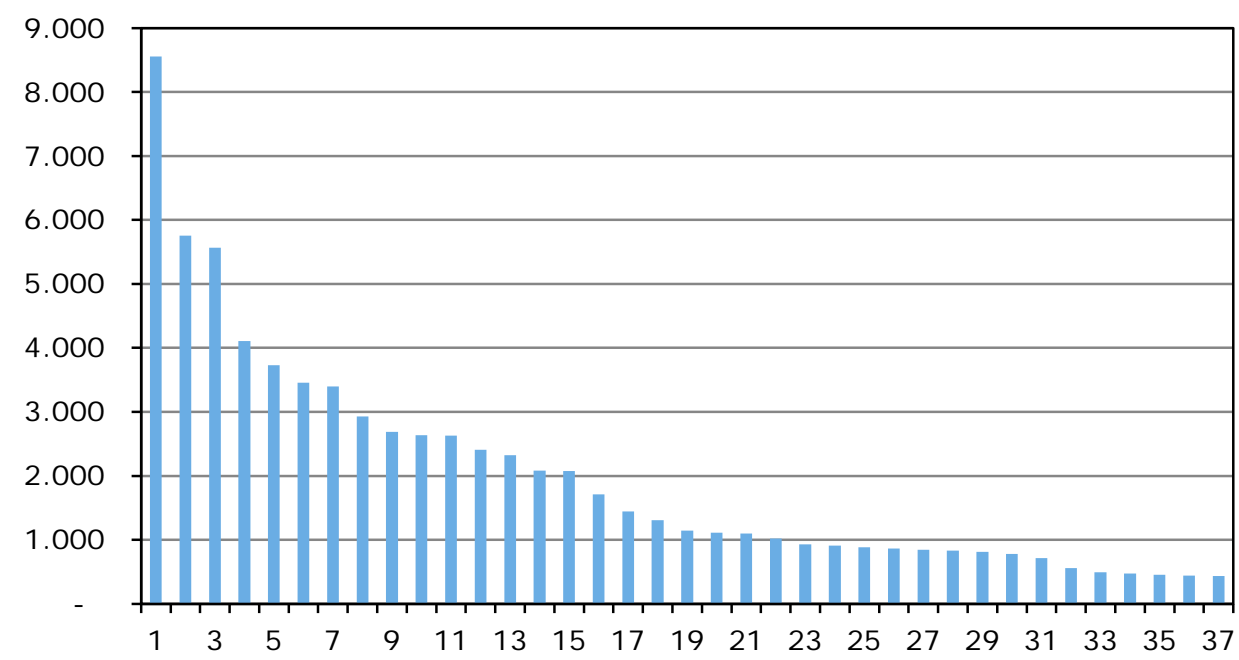

Figuur 16 Schepen in de lijnenvisserij die in 2015 in totaal meer dan $400 \mathrm{~kg}$ zeebaars aanlandden, gerangschikt naar de aanlandingen in kilo's Bron: VIRIS.

Uit figuur 16 blijkt dat van de 76 schepen in de lijnenvisserij die in 2015 zeebaars hebben aangeland, er geen van allen meer dan $10.000 \mathrm{~kg}$ hebben aangeland; alle schepen zaten daar (ruim) onder. 


\subsection{Aanlandingen in de flyshootvisserij}

In 2015 waren er 13 schepen in de flyshootvisserij die zeebaars hebben aangeland. Alle schepen landden in dat jaar $800 \mathrm{~kg}$ of meer zeebaars per schip aan. Deze aanlandingen zijn in figuur 17 gerangschikt naar afnemende aanlandingen. Uit deze figuur blijkt, dat 1 schip meer dan $10.000 \mathrm{~kg}$ heeft aangeland; alle anderen minder dan $10.000 \mathrm{~kg}$.

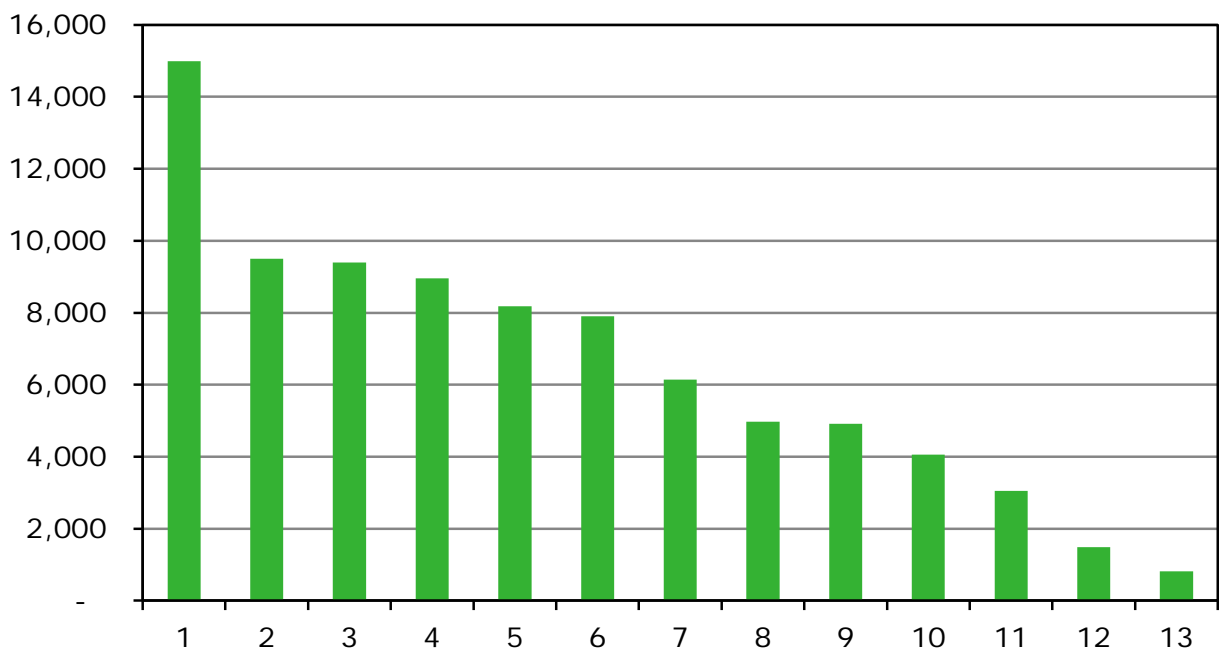

Figuur 17 Schepen in de flyshootvisserij die in 2015 zeebaars aanlandden, gerangschikt naar de aanlandingen in kilo's

Bron: VIRIS.

Kijken we naar de aanlandingen per maand, dan valt op dat 11 van de 13 schepen in één of meer maanden in 2015 meer dan $400 \mathrm{~kg}$ hebben aangeland. Aanlandingen boven $400 \mathrm{~kg}$ zijn vooral geconcentreerd in de periode november-april maar komen voor in alle maanden behalve mei en juli. Voor de meeste van deze 11 schepen gaat het om overschrijdingen van enkele honderden kilo's en in enkele gevallen meer dan 2.000 kilo per maand. Een eventuele aanlandbeperking van $400 \mathrm{~kg}$ per maand zou in 2015 hebben geleid tot een reductie van $52.450 \mathrm{~kg}$. Dit is ongeveer $62 \%$ van de aanlandingen. Aanvullende toepassing van de beperking van maximum $3 \%$ van het totale gewicht in zeebaars zou in 2015 geen aanvullend effect hebben gehad; in alle gevallen was de 400 kg-regel meer beperkend.

De zeebaarsaanlandingen en daarmee ook het aandeel van zeebaars in de besomming van de schepen in de flyshoot visserij kent een duidelijk seizoenspatroon (zie figuur 18; cijfers uit 2014). 


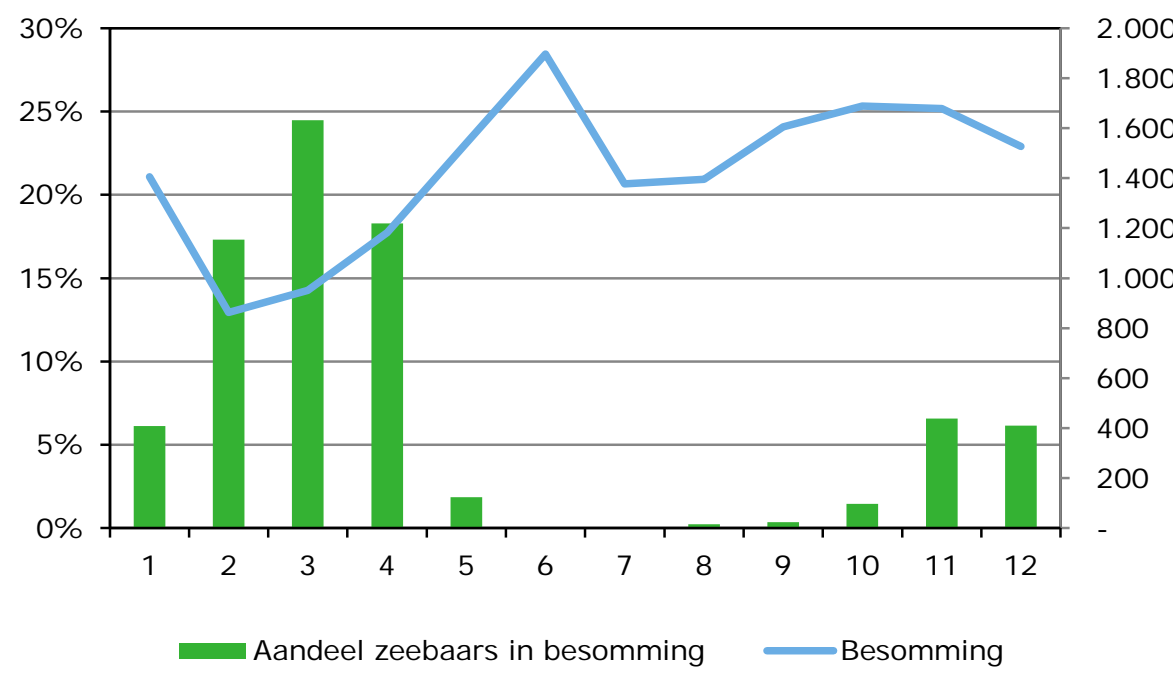

Figuur 18 Seizoensverloop aandeel zeebaars opbrengsten in totale besomming van de flyshootvisserij (2014)

Bron: VIRIS en Bedrijveninformatienet.

Uit figuur 18 blijkt dat er van november tot mei significante hoeveelheden zeebaars aangeland worden, met een piek in de maanden februari-april. In deze periode is de totale besomming relatief lager dan in de andere maanden, maar is het belang van zeebaars juist relatief hoog (rond $20 \%$ ). Van mei tot en met oktober wordt er door de flyshooters nauwelijks zeebaars aangeland. 


\section{Conclusies, discussie en aanbevelingen}

\section{$6.1 \quad$ Conclusies}

In dit rapport geven we in zeven scenario's de resultaten weer van een analyse van de potentiële impact van verschillende mogelijke beschermingsmaatregelen voor zeebaars op aanlandreductie en op de economische opbrengsten van de Nederlandse schepen die commercieel op zeebaars vissen, uitgesplitst naar het type visserij. De uitkomsten van de scenario's kunnen beschouwd worden als indicatie van de impact van de onderliggende maatregelen. Deze analyse is uitgevoerd op basis van de bij Wageningen Economic Research en Wageningen Marine Research aanwezige gegevens en modellen. De belangrijkste conclusies zijn, gegeven de aannames uit paragraaf 1.3 (onder andere gelijkblijvende visserijactiviteiten en gelijkblijvend kostenniveau), als volgt:

- In de Nederlandse situatie zijn de handlijnvissers economisch gezien relatief het meest afhankelijk van de zeebaars. De andere tuigcategorieën zijn op enkele staandwantschepen na (economisch gezien relatief veel) minder afhankelijk van zeebaars maar landen samen in absolute zin een vergelijkbare hoeveelheid zeebaars aan als de handlijnvisserij.

- Van alle scenario's dalen de aanlandingen ten opzichte van 2014 het meest in scenario 1 ('zero catch'), er wordt daarbij nauwelijks zeebaars meer aangeland. De aanlandingen dalen het minst in scenario 3 (aanlandverbod voor het hele jaar voor zeebaars voor alle tuigen behalve flyshoot en gesleepte tuigen); hierbij gaat het om een daling van $43 \%$.

- In scenario 1A en 5A betekent een reductie van de toegestane aanlandingen waarschijnlijk in dezelfde mate ook een reductie in de vangst van zeebaars omdat hier een visverbod geldt voor de kwadranten waar (veel) zeebaars wordt gevangen. In de overige scenario's wordt de reductie van aanlandingen bereikt door een aanlandverbod dat in de praktijk neerkomt op een aanlandingsverbod.

- Tegenover de grotere zekerheid die scenario 1A en 5A bieden ten aanzien van de reductie van de vangsten staat wel een veel grotere daling van inkomsten voor de vloot dan in de overige scenario's. Zo wordt er in scenario 1A per kg zeebaarsvangstreductie 623 euro aan besomming ingeleverd en 122 euro aan winst. In scenario 5A is dit respectievelijk 334 en 172 euro per kilo zeebaarsvangstreductie. In de overige scenario's liggen de daling van besomming en winst per kg zeebaarsvangstreductie in de orde van de prijs van zeebaars (11-13 €/ kg). De verdelingseffecten over de verschillende tuigcategorieën verschillen natuurlijk wel sterk voor de verschillende scenario's. 


\subsection{Discussie}

\subsubsection{Discussie naar aanleiding van de zeven scenario's}

- In dit rapport zijn de meeste maatregelen gebaseerd op een reductie in aanlandingen. Aanlandingen zeggen echter in de praktijk minder over de daadwerkelijke vangsten. Dit is een relevant gegeven in het licht van de reden waarom er maatregelen genomen worden: het beschermen van de populatie zeebaars. Zo hoeft een reductie in aanlandingen niet per definitie een reductie in vangsten te betekenen. Gevangen zeebaars kan immers na vangst overboord gezet worden indien deze niet aangeland mag worden. In welke mate aanlandings-gerelateerde maatregelen effecten hebben op vangsten (inclusief discards) en daarmee de zeebaarspopulatie vergt nader onderzoek.

- Voor de analyse van de economische effecten is 2014 als basisjaar gebruikt omdat dit het laatste jaar is waarvoor economische gegevens beschikbaar waren. Wij zijn ons ervan bewust dat 2014 geen representatief jaar is voor wat betreft de aanlandingen en populatie omdat deze beiden sindsdien significant lager zijn (zie ook figuur 2). Daarom hebben we in grafieken en figuren waar het uitsluitend gaat om de aanlandingen de meest recente gegevens gebruikt (2015). Waar het gaat om de aanlandingen enerzijds en opbrengst, besomming of waarde anderzijds, is 2014 als uitgangspunt gebruikt. Omdat de aanlandingen in 2015 en 2016 verder zijn gedaald zullen de effecten van de zeven scenario's door die jaren ook verschillen. Omdat er nog geen economische data beschikbaar was voor die jaren hebben wij die analyse niet kunnen uitvoeren. Een verdere analyse voor deze recente jaren vergt nader onderzoek.

- In deze analyse is verondersteld dat de visserijactiviteiten niet wijzigen ten opzichte van 2014. Dit betekent dat:

- ervan uit wordt gegaan dat door ieder schip precies evenveel trips naar dezelfde gebieden en met hetzelfde brandstofverbruik en andere kosten als in het basisjaar 2014 worden gemaakt.

- daarbij ook wordt verondersteld dat in de scenario's waarin een visverbod is ingesteld voor bepaalde tuigen of bepaalde gebieden wordt de verboden visserijactiviteit wordt gestopt zonder dat vervangende activiteiten worden ontplooid.

In de praktijk echter, zullen vissers hun gedrag en activiteiten naar alle waarschijnlijkheid aanpassen aan de veranderde omstandigheden. In welke mate deze aanpassingen invloed hebben op het economisch resultaat viel buiten de scope van dit onderzoek. Met een verdere analyse van vervangende activiteiten (met bijbehorende kosten en opbrengsten) kan dit onderzocht worden.

- In de voor dit rapport uitgevoerde analyse worden op basis van bestaande gegevens maatregelen doorgerekend voor de commerciële visserij. Omdat er geen up-to-date gegevens beschikbaar zijn over de aanlandingen en economische opbrengst van de recreatieve visserij valt dit type visserij buiten de scope van dit onderzoek. Om een compleet beeld te krijgen van alle mogelijk effecten kan het doorrekenen van de effecten voor de recreatieve visserij een waardevolle aanvulling zijn op deze analyse.

- Naleving van zowel een vangst- als aanlandingsverbod kan betekenen dat de zeebaars wordt vermeden maar ook dat de zeebaars overboord wordt gezet. In het laatste geval zal de effectiviteit van de in te zetten maatregel afhankelijk zijn van de mate waarin de zeebaars het teruggooien overleeft. Om de effectiviteit van deze maatregelen te bepalen zal nader onderzoek nodig zijn naar de overleving van zeebaars in de verschillende tuigcategorieën. 


\subsubsection{Discussie naar aanleiding van de voor 2017 vastgestelde maatregelen}

Nadat eind 2016 de definitieve beschermende maatregelen voor 2017 bekend zijn geworden, ${ }^{5}$ is globaal in kaart gebracht wat dit zou kunnen betekenen voor de zeebaarsaanlandingen. Hiervoor is dus geen uitgebreide economische impactanalyse uitgevoerd zoals voor de zeven scenario's. Deze maatregelen wijken enigszins af van de in deze analyse doorberekende scenario's, op de volgende drie punten:

1. Voor beroepsvissers met gesleept vistuig (onder andere flyshoot) geldt een bijvangstpercentage van $3 \%$ per reis/op het moment van controle met een maximale aanvoer van $400 \mathrm{~kg}$ per maand.

2. Voor staandwantvissers is de maximale aanvoer vastgesteld op $250 \mathrm{~kg}$ per maand.

3. Voor de handlijnvissers geldt dat er in de maanden januari en april tot en met december in totaal 10 ton zeebaars aangevoerd mag worden.

Worden deze maatregelen vergeleken met de aanlandingen in 2015, dan valt het volgende op:

- In 2015 waren er 13 schepen in de flyshootvisserij die zeebaars hebben aangeland. Van deze 13 schepen waren er 11 die in één of meerdere maanden meer dan $400 \mathrm{~kg}$ hebben aangeland. Een eventuele aanlandbeperking van $400 \mathrm{~kg}$ zou in 2015 tot een reductie van $52.450 \mathrm{~kg}$ hebben geleid. Dit betreft ongeveer $62 \%$ van de aanlandingen. Een aanvullende beperking in toegestane aanlandingen van maximum 3\% van het totale gewicht in zeebaars zou in 2015 geen aanvullend effect hebben gehad; in alle gevallen zou de $400 \mathrm{~kg}$-regel beperkender zijn.

- In 2015 waren er 60 staandwantschepen die zeebaars hebben aangeland. Hiervan hebben er 11 schepen in één of meer maanden meer dan $250 \mathrm{~kg}$ aangeland. Aanlandingen boven de $250 \mathrm{~kg}$ kwamen alleen voor in de maanden mei en juli-oktober. Een eventuele aanlandbeperking van $250 \mathrm{~kg}$ per maand zou in 2015 tot een aanlandreductie van $6.004 \mathrm{~kg}$ hebben geleid, wat ongeveer $35 \%$ is van de totale aanlandingen.

- In 2015 waren er 76 schepen in de lijnenvisserij die zeebaars hebben aangeland. Hiervan hebben er geen van allen meer dan $10.000 \mathrm{~kg}$ aangeland; alle schepen zaten daar (ruim) onder.

5 http://www.visned.nl/nl/nieuws/item/id/31263/visserijraad-geeft-goed-perspectief-voor-2017 


\section{Databronnen, literatuur en websites}

\section{Databronnen}

Bedrijveninformatienet van Wageningen Economic Research

VIRIS, Ministerie van Economische Zaken

\section{Literatuur en websites}

Europese Commissie (2016), COM(2016) 698 final - 2016/0344 (NLE) - Voorstel voor een verordening van de raad tot vaststelling, voor 2017, van de vangstmogelijkheden voor sommige visbestanden en groepen visbestanden welke in de wateren van de Unie en, voor vissersvaartuigen van de Unie, in bepaalde wateren buiten de Unie van toepassing zijn http: / / ec. europa.eu/transparency/regdoc/rep/ 1/2016/ NL/COM-2016-698-F1-NL-MAI N.PDF

ICES (2015a), ICES Advice on fishing opportunities, catch, and effort Celtic Seas and Greater North Sea Ecoregions - 5.3.43 Sea bass (Dicentrarchus labrax) in Divisions IVb and c, VIIa, and VII $\mathrm{d}-\mathrm{h}$ (Central and South North Sea, Irish Sea, English Channel, Bristol Channel, Celtic Sea) http://www. ices.dk/sites/pub/Publication\% 20Reports/Advice/2015/2015/Bss-47. pdf

ICES (2015b), Report of the Working Group on Recreational Fisheries Surveys (WGRFS) 1- 5 J une 2015. ICES CM 2015\SSGIEOM: 10. 109 pp.

Lopez R., de Pontual H., Bertignac M. \& Mahevas S. (2015), What can exploratory modelling tell us about the ecobiology of European sea bass (Dicentrarchus labrax): a comprehensive overview.

Van der Hammen T. \& de Graaf, M. (2015), Recreational fisheries in the Netherlands: analyses of the 2012-2013 online logbook survey, 2013 online screening survey and 2013 random digit dialing screening survey. I MARES report C042/15. 55 pp.

VisNed (2016), Visserijraad geeft goed perspectief voor 2017

http://www. visned. nl/nl/nieuws/item/id/31263/visserij raad-geeft-goed- perspectief-voor-2017 
Wageningen Economic Research Postbus 29703

2502 LS Den Haag

T 0703358330

Ecommunications.ssg@wur.nl

www. wur.nl/economic-research

Wageningen Economic Research RAPPORT

2017-008
De missie van Wageningen University \& Research is 'To explore the potential of nature to improve the quality of life'. Binnen Wageningen University \& Research bundelen Wageningen University en gespecialiseerde onderzoeksinstituten van Stichting Wageningen Research hun krachten om bij te dragen aan de oplossing van belangrijke vragen in het domein van gezonde voeding en leefomgeving. Met ongeveer 30 vestigingen, 5.000 medewerkers en 10.000 studenten behoort Wageningen University \& Research wereldwijd tot de aansprekende kennisinstellingen binnen haar domein. De integrale benadering van de vraagstukken en de samenwerking tussen verschillende disciplines vormen het hart van de unieke Wageningen aanpak. 



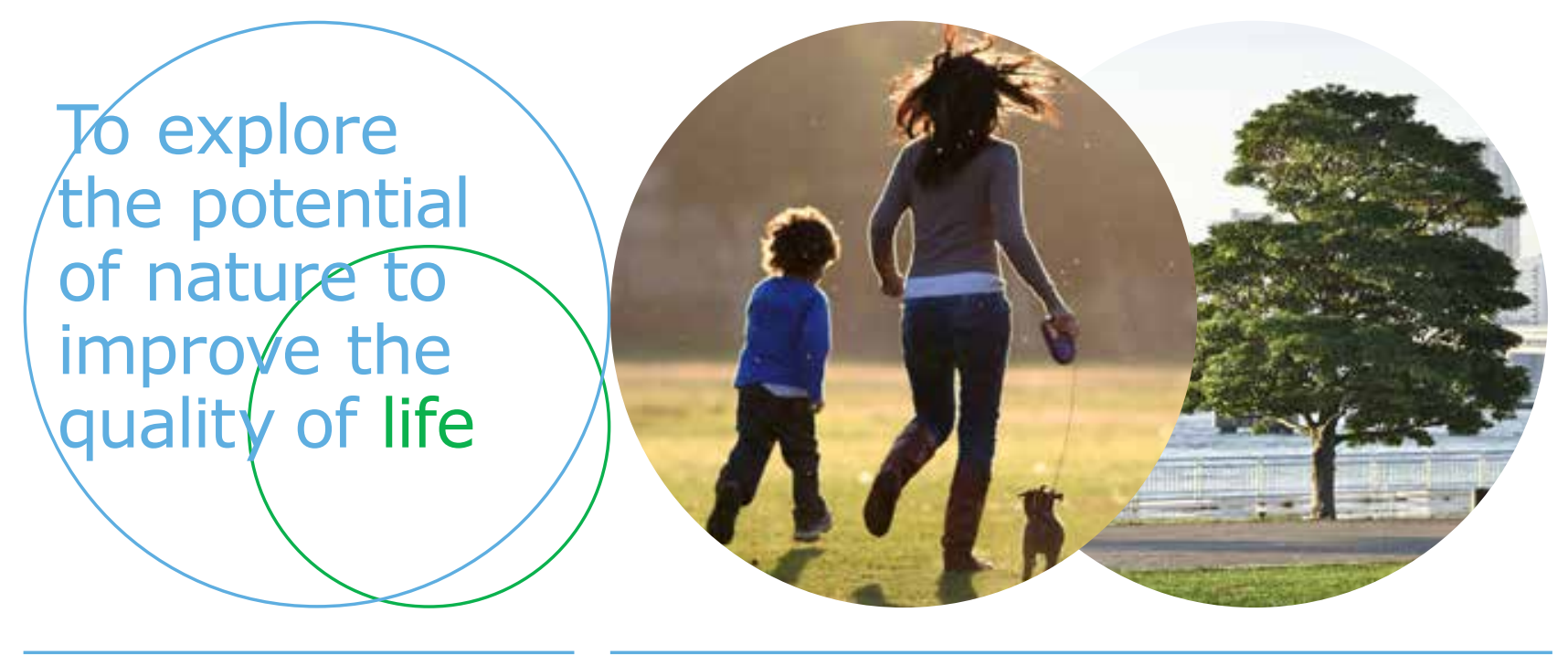

Wageningen Economic Research P.O. Box 29703

2502 LS Den Haag

The Netherlands

E communications.ssg@wur.nl

www.wur.eu/economic-research

Rapport 2017-008

ISBN 978-94-6343-150-7
The mission of Wageningen University and Research is "To explore the potential of nature to improve the quality of life". Under the banner Wageningen University \& Research, Wageningen University and the specialised research institutes of the Wageningen Research Foundation have joined forces in contributing to finding solutions to important questions in the domain of healthy food and living environment. With its roughly 30 branches, 5,000 employees and 10,000 students, Wageningen University \& Research is one of the leading organisations in its domain. The unique Wageningen approach lies in its integrated approach to issues and the collaboration between different disciplines. 